\title{
Öğretmen Adaylarının Öğretmen Profesyonelliğine İlişkin Görüşlerinin İncelenmesi
}

\author{
Sibel Güven ${ }^{1}$, Emel Kırat ${ }^{2}$
}

${ }^{I}$ Temel Eğitim Bölümü, Eğitim Fakültesi, Çanakkale Onsekiz Mart Üniversitesi, Çanakkale, Türkiye, s_guven@comu.edu.tr

${ }^{2}$ Temel Eğitim Bölümü, Eğitim Fakültesi, Çanakkale Onsekiz Mart Üniversitesi, Çanakkale, Türkiye, emelkiratt@gmail.com

\section{Sorumlu Yazar: Sibel Güven}

Makale Türü: Araştırma Makalesi

Kaynak Gösterimi: Güven, S., \& Kırat, E., (2021).Öğretmen adaylarının öğretmen profesyonelliğine ilişkin görüşlerinin incelenmesi. Eğitimde Kuram ve Uygulama, 17(2), 79-104. doi: 10.17244/eku.995986

Etik Not: Araştırma ve yayın etiğine uyulmuştur. Bu araştırma için Çanakkale Onsekiz Mart Üniversitesi Lisansüstü Eğitim Enstitüsü Etik Kurulundan etik onay alınmıştır (Tarih: 08.04.2021, Sayı: 07/23).

\section{Investigation of Pre-service Teachers Views on Teacher Professionalism}

$$
\text { Sibel Güven }{ }^{1} \text {, Emel Kırat }{ }^{2}
$$

${ }^{1}$ Departments of Primary Education, Faculty of Education, Çanakkale Onsekiz Mart Üniversitesi, Canakkale, Turkey,

$$
\text { s_guven@comu.edu.tr }
$$

${ }^{2}$ Departments of Primary Education, Faculty of Education, Çanakkale Onsekiz Mart Üniversitesi, Canakkale, Turkey, ,

Corresponding Author: Sibel Güven

\section{emelkiratt@gmail.com}

Article Type: Research Article

To Cite This Article: Güven, S., \& Kırat, E., (2021).Öğretmen adaylarının öğretmen profesyonelliğine ilişkin görüşlerinin incelenmesi. Ĕgitimde Kuram ve Uygulama, 17(2), 79-104. doi: 10.17244/eku.995986

Ethical Note: Research and publication ethics were followed. For this research, the ethical approval was obtained from the Ethics Committee of Canakkale Onsekiz Mart University School of Graduate Studies (Date: 08.04.2021, Number: 07/23). 


\title{
Öğretmen Adaylarının Öğretmen Profesyonelliğine İlişkin Görüşlerinin İncelenmesi
}

\author{
Sibel Güven ${ }^{1}$, Emel Kırat ${ }^{2}$ \\ ${ }^{I}$ Temel Eğitim Bölümü, Eğitim Fakültesi, Çanakkale Onsekiz Mart Üniversitesi, Çanakkale, Türkiye \\ s.guven@comu.edu.tr, ORCID: 0000-0003-4550-7297 \\ ${ }^{2}$ Temel Eğitim Bölümü, Eğitim Fakültesi, Çanakkale Onsekiz Mart Üniversitesi, Çanakkale, Türkiye \\ emelkiratt@gmail.com, ORCID: 0000-0001-5152-7214
}

\begin{abstract}
$\ddot{\mathbf{O z}}$
Farklı mesleki alanlarda öne çıkan profesyonellik kavramının öğretmen profesyonelliği çerçevesinde değerlendirildiği bu araştırmada öğretmen adaylarının profesyonellik kavramına ilişkin görüşlerinin incelenmesi amaçlanmıştır. Bu doğrultuda profesyonel kişi ve öğretmen özellikleriyle birlikte öğretmenlik sürecine hazırlığı temsil eden lisans eğitimi, profesyonel kişi ve öğretmenlerin sahip olması gereken özellikler öğretmen adaylarının araştırma sürecine katılımıyla değerlendirilmiştir. Nitel yöntemin izlendiği bu araştırma durum çalışması deseninde yürütülmüştür. Bir devlet üniversitesinde Okul Öncesi Öğretmenliği, Türkçe Öğretmenliği ve Fen Bilimleri Öğretmenliği bölümlerinin 3. ve 4. sınıflarında öğrenim görmekte olan toplam 88 öğretmen adayı araştırmanın çalışma grubunu oluşturmaktadır. Elde edilen veriler içerik analizi tekniği ile analiz edilmiş, ana temaları oluşturan yapılar doğrultusunda sonuçlara ulaşıılmıştır. Araştırmadan elde edilen sonuçlar öğretmen adaylarının profesyonel öğretmenleri mesleki alanda uzmanlaşan, gelişime ve yeniliğe açık olan, geleceği inşa eden, iş birliği kurabilen kişiler şeklinde değerlendirdiklerini göstermektedir. Bununla birlikte öğretmen profesyonelliği sürecinde uygulama boyutları birçok noktada vurgulanarak bu boyutun eksikliği ve geliştirilmesine yönelik öneriler öne çıkan sonuçlar arasında yer almaktadır.
\end{abstract}

\section{Makale Bilgisi}

Anahtar kelimeler: Etkili öğretmen, öğretmen profesyonelliği, profesyonellik

Makale Geçmişi:

Geliş:15 Eylül 2021

Düzeltme:1 Aralık 2021

Kabul: 4 Aralık 2021

Makale Türü: Araştırma Makalesi

\section{Investigation of Pre-service Teachers Views on Teacher Professionalism}

\begin{abstract}
In this study, in which the concept of professionalism, which stands out in different professional fields, is evaluated within the framework of teacher professionalism, it is aimed to examine the views of teacher candidates on the concept of professionalism. In this vein, the qualifications that the undergraduate education, professional person, and teachers should have, which represent the preparation for the teaching process together with the professional person and teacher characteristics, were evaluated with the participation of the teacher candidates in the research process. This research, in which the qualitative method was followed, was conducted in a case study pattern. The study group of the research consists of a total of 88 pre-service teachers studying at the 3rd and 4th grades of Preschool Teaching, Turkish Language Teaching and Science Teaching departments in a state university. The data obtained were analyzed with the content analysis technique, and the results were obtained in line with the structures that constitute the main themes. The results obtained from the research show that pre-service teachers evaluate professional teachers as people who specialize in the professional field, are open to development and innovation, build the future, and can establish cooperation. However, the practice dimensions in the process of teacher professionalism are emphasized at many points, and the lack of this dimension and suggestions for its development are among the prominent results.
\end{abstract}

\author{
Article Info \\ Keywords: Efficient teacher, \\ professionalism, teacher \\ professionalism \\ Article History: \\ Received: 15 September 2021 \\ Revised: 1 December 2021 \\ Accepted: 4 December 2021
}

Article Type: Research Article 


\section{Extended Summary}

\section{Introduction}

Depending on the fact that professionalism points to a dynamic structure, social needs and the services provided are provided by education and training activities. In this direction, the professional evaluation of the teaching profession focuses on the controllability of the authority and skills required by the profession. Professionalism is considered as a professional value. This value is the source of shaping the roles of teachers within the framework of professional standards in the educational process in terms of the teaching profession.

Considering the needs of the 21 st century, the aim of the research is to examine the views of teacher candidates to determine the professional characteristics of the teaching profession. In line with the main purpose, the dimensions constituting the sub-objectives of the research in question are as follows:

- What are the pre-service teachers' thoughts on their reasons for professionalism and professionalism in the profession?

- How do prospective teachers evaluate the teaching profession? What are the points associated with these assessments?

- In which dimensions do pre-service teachers consider professional teacher characteristics?

- What are the concepts and statements that pre-service teachers put forward with their reasons for supporting professional development?

- What basic dimensions do effective teacher characteristics consist of according to teacher candidates?

- How do prospective teachers relate cooperation processes with the teaching profession?

- In which aspects do prospective teachers evaluate their undergraduate education within the scope of their impact and contribution to professional life?

- What are the opinions of teacher candidates about the arrangements that can be made in teacher education as of today? In this direction, what suggestions were expressed for the process?

\section{Method}

In the research, in which the views on being professional in the profession, professional and effective teacher characteristics, professional development, and cooperation processes associated with teacher professionalism were examined, it was aimed to reach the evaluations on the subject with the case study design.

In the 2020-2021 academic year, 88 pre-service teachers studying in the departments of Preschool Education Teaching, Turkish Language Teaching and Science Teaching at the education faculty of a state university and taking the teaching practice course formed the study group of the research.

A semi-structured interview form was used in this study, in which teacher professionalism was examined from the perspectives specific to the profession, and the views of pre-service teachers about the process were discussed by considering the relational contexts in the dimensions of skill, competence and development. In the first part of the interview form, the pre-service teachers were presented with an answer field where they could specify their gender and department they are studying. The second part consists of 10 semi-structured open-ended questions associated with the sub-objectives of the research.

During the data collection phase of the research, the interview form prepared by the researchers was delivered to the participants who were studying in the departments determined in the study group and who had taken the teaching practice through Google Forms. In this process, the participants participated in the process by answering 10 open-ended questions in the interview form in written form.

The data collected through semi-structured interviews were analyzed by content analysis technique. At this stage, sub-themes were formed depending on the main themes and opinions in relation to the sub-objectives of the research. The fact that the participants evaluated more than one sub-dimension in each question affected the total frequency values of the main themes. The total frequency values presented in the findings represent the total number of views on the themes.

\section{Findings}

In the current research, 10 different main themes related to professionalism constitute the sub-findings of the research. The expression levels of the sub-themes determined based on the opinions within the framework of these main themes are presented in numerical expressions.

When the views of the pre-service teachers explaining the concept of professionalism and defining professional persons are examined, it is seen that 44 pre-service teachers expressed their opinions within the scope of the sub-theme "Developing/Specializing in the Field", which has the highest percentage among the 21 sub-themes. 
When the opinions of the pre-service teachers regarding professionalism are examined, it is seen that 28 preservice teachers expressed their opinions within the scope of the sub-theme "Working with Ideal Qualifications", which has the highest percentage among the 22 sub-themes determined.

When the opinions describing the characteristics that teachers should have are examined, it is seen that 24 teacher candidates expressed their opinions within the scope of the "Building the Future" sub-theme, which has the highest percentage among the 20 sub-themes determined.

When the opinions in which professionalism and teaching characteristics are presented in relation, it is seen that 41 teacher candidates expressed their opinions within the scope of the "Being Open to Development/Innovation" subtheme, which has the highest percentage among the 32 sub-themes determined.

When the opinions expressed by the pre-service teachers about the structures that lead professional development are examined, it is seen that 26 teachers expressed their opinions within the scope of the "Educational Meetings/Courses" sub-theme, which has the highest percentage among the 24 sub-themes.

When the views of the pre-service teachers expressing the structures that make up the effective teacher characteristics of the teachers are examined, it is seen that 25 pre-service teachers expressed their opinions within the scope of the "Having Communication Skills" sub-theme, which has the highest percentage among the 26 sub-themes determined.

When the expressions of the pre-service teachers are examined in terms of their professional processes and the dimensions of cooperation that can be established in this process, it is seen that 11 pre-service teachers have expressed their opinions within the scope of the sub-themes "Personal/Professional Development" and "Diversity in Thinking Skills", which have the highest percentage of 26 sub-themes.

When the dimensions that teacher candidates associate with the teaching profession with their undergraduate education, it is seen that 41 teacher candidates expressed their opinions within the scope of the "Effective" sub-theme, which has the highest percentage among the 3 sub-themes.

When the statements that the pre-service teachers evaluated in terms of proficiency in their undergraduate education, it was observed that 49 pre-service teachers expressed their opinions within the scope of the "Not Sufficient" sub-theme, which has the highest percentage among the 3 sub-themes determined. When the other sub-themes related to these proficiency levels were examined, 22 pre-service teachers found the undergraduate education process partially sufficient, while 15 pre-service teachers stated that the process was sufficient in this dimension.

When the processes to be followed in teacher education or the situations in which the points to be considered are expressed within the scope of the undergraduate education that the prospective teachers received, it is seen that 68 teacher candidates expressed their opinions within the scope of the "Applied Course/Internship" sub-theme, which has the highest percentage among the 11 sub-themes determined.

\section{Discussion and Conclusion}

The results obtained from the expressions that teacher candidates initially defined the concept of professionalism within the framework of personal characteristics focused on the dimensions of being a field expert, having competence depending on their profession, and organizing affective processes as a professional person. Similarly, the evaluations made for specialization in the field are explained by the fact that the person is equipped with knowledge.

The opinions of the participants on professional professionalism are in the direction of expressing the person as an expert, knowledgeable and open to development. Among these dimensions, the most prominent opinions are to define the teacher as the "ideal person". Pre-service teachers describe the ideal teacher as a person who has all the requirements of the profession and reflects them to the process in the best way.

According to the statements of teacher candidates explaining the characteristics of the teaching profession, it is seen that there are many statements about the idea that teachers contribute to the formation of individuals' futures. These statements correspond to the dimension of characterizing teaching as a future-oriented and basic profession. Pre-service teachers interpreted this profession as raising students for other professions and educating the society.

In another theme, in which teacher professionalism is handled within the framework of the characteristics possessed, it has been stated that people who are qualified as professional teachers should be open to development and innovation, have professional competence and communication skills. Frequent expression of these dimensions can be associated with educational processes, supporting development in the general framework, and the necessity of keeping up with innovations with the changing process.

In the views emphasizing professional development and the dimensions constituting this process, expressions about educational meetings and experiences were frequently encountered. It has been stated that the arrangements regarding the classroom environment, school environment, and out-of-school environment will contribute to the process in a way that supports professional development. In this context, it is concluded that professional development will reach higher levels with experiences and educational steps. 
According to pre-service teachers, an effective teacher is a teacher with good social skills and communication skills related to the social field. In this direction, it has been concluded that the social environment, communication processes and teacher competencies constitute the whole of the educational process.

When the opinions about the cooperation dimension, which is seen as related to the social environment and frequently encountered by the teachers in the professional process evaluations, are examined, it is concluded that the cooperation contributes to the development and diversity. In this dimension, both personal and professional development are established through cooperation processes with the influence of the social environment and are a source for the formation of thinking skills.

According to the opinions of the participants, in which undergraduate education is evaluated in terms of effectiveness, undergraduate education seems to be effective on the teaching profession. The statements are that the undergraduate education process is a guide for teachers and that this process is the basis of teacher training.

Most of the teacher candidates find their undergraduate education sufficient. It has been determined that there are suggestions for the development of existing structures in the dimensions where the contents of the lessons taken, and these contents are discussed in terms of quality.

When the opinions about non-professionalism are examined together with teacher education, it is concluded that it is concentrated in the implementation processes, as in the dimensions of effectiveness and competence. Restructuring of course contents and existing teacher training dimensions and preparing them to meet current needs are among the suggestions frequently stated by pre-service teachers. 


\section{Giriş}

Dünya genelinde farklı alanlara yönelik özel nitelikler taşıyan meslekler, temelde bilgi ve beceri boyutlarına dayandırılmaktadır. Alana yönelik temel amaçlar doğrultusunda iş olarak görülen bu yapı uzmanlık boyutunda bir eğitimle şekillenmektedir. Mesleki alanlar uzman bilgi tabanına dayalı olarak kurulmakta ve bilgi sistemlerini bünyesinde barındırmaktadır (Kurutkan, 2010). Bu amaçlar yönünde meslekler temel uğraş alanlarını oluşturmakta ve birtakım standartlar içermektedir. Uzmanlık sağlanan alanda bilgi ve beceri boyutlarının özel nitelikte olması meslek kavramını benzer ifadelerden ayıran bir özellik olarak literatürde yer almaktadır (Barley, 1996 Akt., Karasu, 2001).

Her alanda farklı uygulamalarla birlikte hayata geçirilen uğraşlar eğitsel faaliyetlerle desteklenerek mesleki boyut kazanmaktadır. Bu süreçte uzmanlaşılan bilgi tabanına ihtiyaç duyulmakta, teknik yapı doğrultusunda mesleki süreçlere yön verilmektedir. Profesyonellik kavramı bu noktada meslek ile ilişkilendirilmekte, mevcut işin profesyonelleşme süreçlerine dahil edilerek mesleğe dönüşümü olarak ele alınmaktadır (Karasu, 2001).

Profesyonel gelişim, mevcut durumun iyileştirilmesi ve standartların yükseltilmesi şeklinde ifade edilmektedir. $\mathrm{Bu}$ açıdan profesyonel gelişim ile toplumsal statünün yükseltilmesi ve bu doğrultuda planlamaların oluşturulması hedeflenmektedir. Gelişim için sunulan hizmet, profesyonellik anlayışının temellerini oluşturmaktadır. Profesyonellik kavramına yönelik fikir çeşitliliği bu alanda farklı yorumlamaları beraberinde getirmiştir. Evans (2011) profesyonelliği mesleki kontrol, sosyal yapının dinamizmi, bilginin uyarlanması ve sosyal sermaye açısından kullanılış biçimi şeklinde değerlendirmiş̧tir. Sosyolojik boyutta bu yapı normatif değerler bütünü olarak ele alınmış ve profesyonellik olgusu sosyal ilişkilerle bütünleştirilmiş̧ir. Robson (2006) ise profesyonelliği sorumluluk alabilme, özerk olabilme ve profesyonel bilgiye ulaşma şeklinde temel bileşenlerle tanımlamıştır.

Literatürdeki tanımlar dikkate alındığında profesyonelliğin dinamik bir yapıyı işaret etmesine bağlı olarak toplumsal gereksinimler ve ortaya konulan hizmetler eğitim öğretim faaliyetleri ile sağlanmaktadır. Bu yönde öğretmenlik mesleğinin profesyonel açıdan değerlendirilmesiyle mesleğin gerektirdiği yetki ve becerilerin kontrol edilebilirliğine odaklanılmaktadır. Profesyonellik mesleki bir değer şeklinde ele alınmaktadır. Bu değer öğretmenlik mesleği açısından eğitsel süreç içerisinde öğretmen rollerinin mesleki standartlar çerçevesinde şekillenmesine kaynaklık etmektedir. Söz konusu durumda profesyonelliği şekillendiren faktörler de öğretmen hesap verilebilirliği ve performans kapsamında değerlendirilmektedir (Sachs, 2016).

Evans (2008)'a göre profesyonellik üç temelden oluşmaktadır. Bu anlamda talep edilen, öngörülen ve hayata geçirilen (diğer bir deyişle yasalaştırılan) profesyonellik benimsenen amaç ve içeriklerin gelişimi yönüne vurgu yapmaktadır. Eğitim alanındaki paydaşların da profesyonellik süreçleri bu bakış açısına bağlı olarak meslek kültürü çerçevesinde ilerleme kaydedilmesi ile gerçekleşmektedir. Söz konusu öğretmenlik mesleğinin doğası ve kapsamı, yerine getirilmesi hedeflenen vizyonlara bağlı olarak belirlenmektedir.

Öğretmen profesyonelliğinin gelişim süreci Hargreaves (2000)'e göre dört aşamadan oluşmaktadır. Bu süreçte başlangıçta profesyonellik öncesi aşama yer almaktadır. Bu aşamada öğretmenler teorik açıdan donanım sahibi olmakla birlikte süreci yönetme ve kontrol sağlama açısından güçlük çekmektedir. Bir sonraki aşama olan özerk profesyonel aşamasında ise öğretmenlerin program yapısı da dahil olmak üzere süreci yönetme konusunda esnek ve özerk bir yapıda oldukları görülmektedir. Sonrasında meslektaşlar arası iş birliğine dayalı profesyonellik aşamasında öğretmenler, ortak amaçlar doğrultusunda hareket etmekte ve uygulama süreçlerini mevcut gelişmelere bağlı olarak şekillendirmektedir. Profesyonellik sonrası şeklinde adlandırılan son aşamada ise bu duruma bağlı olarak öğretmenlerin öğrenci ve öğrenci çevresi boyutunda denge kurmaları, ileri beceriler olarak kabul edilen boyutları amaçlara uygun biçimde gerçekleştirmeleri beklenmektedir.

Günümüz şartlarına göre öğretmen profesyonelliği yeni iş gücü, çocukların gündemi ve ebeveynlerle bağlantılı olarak farklılaşmaktadır. İş gücü piyasası ve genç istihdamının ele alındığı On Birinci Kalkınma Planı'nda (2019 - 2023) belirtildiği üzere eğitim personellerinin iş gücünün artışıyla birlikte sektördeki öğretmen sayılarında artışa ihtiyaç duyulmaktadır. Bu noktada sayının artışı alan ile ilişkili eğitim ve değerlendirme programlarına duyulan ihtiyacı ve nicelik sorununu beraberinde getirmektedir (T.C. Kalkınma Bakanlığı, 2018).

Hargreaves (2000)'in ele aldığ 1 dört profesyonel gelişim aşamasına bağlı olarak öğretmen profesyonelliği pedagojik, kişisel, sosyal ve mesleki yeterlilikler şeklinde değerlendirilmektedir. Bu boyutların temelinde öğretmen profesyonelliği nitelikli bir mesleki geçmişe sahip olmakla birlikte mesleki eğitim standartlarını karşılayan yeterliliklere ulaşabilme noktasına göre belirlenmektedir (Wardoyo ve Herdiani, 2017).

Araştırma konusu ile ilişkili olarak Siri (2020), öğretmen yeterliliği ve bağlılığının öğretmen profesyonelliğini geliştirme üzerine olan etkiyi incelemeyi amaçlamıştır. Öğretmen yeterliliği ve bağlılığının profesyonel öğretmen performansı üzerinde anlamlı etkiye sahip olduğu belirlenmiştir. Performansın arttırılması için öğretmenlik mesleğinde yetkinlik ve bağlılığın gerekli olduğu ifade edilmiştir. Li (2019), öğretmenlerin mesleki sorumluluğun profesyonellik algılarında etkili olduğu sonucuna ulaşmıştır. Bununla birlikte bu sorumluluğu oluşturan faktörleri kurumsal çevre, sosyal kültür, kişisel yaşantı olarak sıralamıştır. 
Khizar, Muhammad ve Mushtaq (2019) öğretmen profesyonelliğinin gelişimi ve ulusal mesleki standartlar konusunda gerçekleştirdikleri araştırmada Ulusal Eğitim Politikası'nın ve öğretmenler için ulusal mesleki standartların profesyonelliğin geliştirilmesi üzerinde durmuşlar, Ulusal Eğitim Politikası'nın ve öğretmenler için ulusal mesleki standartların profesyonelliği gerçek anlamda etkilemediğini belirlemişlerdir. Öğretmen yetiştirmedeki mesleki eğitim ve yüksek niteliklerin gerekli olduğu vurgulanan Ulusal Eğitim Politikası'nda öğretmen yetiştirme programının yeniden gözden geçirilmesine ilişkin ihtiyaca vurgu yapılmaktadır. Öğretmen profesyonelliğinde mesleki eğitim ve program yapısı son derece önemli bir yer tutmaktadır.

Son yıllarda öğretmenlik profesyonelliği üzerine odaklanan araştırmalara bakıldığında araştırmaların profesyonellik olgusu ile bağlantılı boyutlar açısından ilişki durumlarının incelendiği görülmektedir. Altınkurt ve Yılmaz (2014) öğretmen profesyonelliği ve iş doyumu arasındaki ilişkiyi öğretmen görüşlerine göre nicel yöntem ile inceleyerek her iki boyut arasında anlamlı bir etkileşime rastlamışlardır. Habibi, Hartinah, Umam, Syazali, Lestari, Abdurrahman ve Jauhariyah'ın (2019) öğretmen profesyonelliği kavramının öğretmenler açısından belirleyici niteliklerinin incelendiği araştırmada yönetsel ve sosyal yeterlilikler araştırma konusunun temelindeki öğretmen profesyonelliği ile ilişkili bulunmuştur.

Öğretmen profesyonelliği kavramıyla ilişkili ögelerin yer aldığı çalışmaların yanı sıra mesleki profesyonellik kavramı da öğretmen görüşleri çerçevesinde nicel araştırma yöntemiyle son yıllarda literatürde yer almıştır. Şenol (2020) mesleki profesyonelliği iş memnuniyeti, öz yeterlik ve mesleki statü kavramlarına, Buyruk ve Akbaş (2021) özerklik kavramına, Zembat ve Küsmüş (2020) sınıf yönetim becerilerine, Karnak (2020) örgütsel mutluluk kavramına, Eroğlu, Erdoğan ve Özbek (2018) mesleki gelişime bağlı olarak incelemiştir. Nitel araştırma yönteminde yürütülen mesleki profesyonellik temelinde Maxwell ve Schwimmer'in (2016) etik eğitim, Werler'in (2015) öğretmen eğitimi temelli araştırmaları da öğretmenlerin katılımıyla gerçekleştirilmiştir.

Araştırmaların öğretmen profesyonelliği ya da mesleki profesyonellik olmak üzere çoğunlukla nicel yönteme dayalı yürütüldüğü ve bu süreçlere öğretmenlerin katılım sağladığı görülmektedir. Öğretmen adaylarının nitel araştırma desenlerinden biri ile konu hakkındaki görüşlerinin belirlenmesi ve temel nitelik değerlendirmeleri araştırmalarda az rastlanan bir çalışma alanı olmuştur. İstatistiki yollarla araştırma sürecinin gerçekleştirilmesinin aksine görüşlerin detaylandırılması ve ifadelerin nedensellik bağlamında incelenebilmesi için nitel yöntem doğrultusunda durum çalışmasının gerçekleştirilmesine ihtiyaç duyulmuştur.

\section{Araştırmanın Amacı}

Bireysel ve toplumsal amaçlarla birlikte 21. yüzyıl ihtiyaçları göz önünde bulundurulduğunda profesyonellik kavramının öğretmenlik mesleği açısından değerlendirilmesi ve bu doğrultuda öğretmenlik mesleğinin profesyonellik özelliklerini belirlemek adına öğretmen adaylarının görüşlerinin incelenmesi araştırmanın amacını oluşturmaktadır. Temel amaç doğrultusunda söz konusu araştırmanın alt amaçlarını oluşturan boyutlar şu şekildedir:

- Öğretmen adaylarının profesyonellik ve meslekte profesyonellik için gerekçelerine ilişkin düşünceleri nelerdir?

- Öğretmen adayları öğretmenlik mesleğini nasıl değerlendirmektedir? $\mathrm{Bu}$ değerlendirmelerin ilişkilendirildiği noktalar nelerdir?

- Öğretmen adayları profesyonel öğretmen özelliklerini hangi boyutlarda ele almaktadır?

- Öğretmen adaylarının profesyonel gelişmeyi destekleme yönünde sebepleriyle birlikte öne sürdüğü kavramlar ve ifadeler nelerdir?

- Öğretmen adaylarına göre etkili öğretmen özellikleri hangi temel boyutlardan oluşmaktadır?

- Öğretmen adayları işbirliği süreçlerini öğretmenlik mesleği ile nasıl ilişkilendirmektedir?

- Öğretmen adayları dahil oldukları lisans eğitimleri mesleki hayata etki ve sağladığı katkılar kapsamında hangi yönleriyle değerlendirmektedir?

- Öğretmen adaylarının günümüz itibariyle öğretmen eğitiminde gerçekleştirilebilecek düzenlemelere yönelik görüşleri nelerdir? Bu doğrultuda sürece yönelik hangi öneriler ifade edilmişsir?

\section{Yöntem}

\section{Araştırma Deseni}

Nitel araştırma desenlerinden biri olan durum çalışması katı ve sistematik kurallardan uzak, söz konusu duruma uygun ideal tip şeklinde ifade edilmektedir. Bu uygunluğu sağlayabilmenin yolu süreçte belli noktalarda esnekliğin var olmasıyla ilişkilendirilmiştir. Ancak bu esneklik, belirleyici bir çerçeveye bağlı oluşmakta ve bünyesinde ayırt edici özellikler barındırmaktadır. İdeal tip şeklinde ifade edilen bu görüşe göre araştırma sürecinde birimler arası karakteristik noktalar mevcuttur. Bu noktalara göre belirlenen güçlü ve zayıf yönler ele alınan duruma göre yorumlanmaktadır (Gerring, 2004). 
Durum çalışmaları; yeni süreç ya da davranışlarla birlikte anlamlandırma konusunda derinliğe sahip nitelikleri detaylı inceleme yolu olarak kabul edilmektedir. Söz konusu sebeplere bağlı olarak güncel olay ya da durumlar hakkında "Nasıl?" ve "Neden?" sorularına yanıt aranmaktadır. Bu yanıtlar kapsamında gerçekleştirilen değerlendirmelerin genellemelere bağlı olmaksızın özel çerçevede ele alınmasına ihtiyaç duyulmaktadır. Durum çalışmalarından hareketle gerçekleştirilen incelemeler, sürecin bütüncül bakış açısıyla değerlendirilmesini sağlamaktadır (Meyer, 2001). Öğretmen profesyonelliği ile ilişkilendirilen meslekte profesyonel olma, profesyonel ve etkili öğretmen özellikleri, profesyonel gelişim, işbirliği süreçlerine ilişkin görüşlerin incelendiği araştırmada durum çalışması deseniyle konu hakkındaki değerlendirmelere ulaşılması hedeflenmiştir.

\section{Çalışma Grubu}

2020-2021 eğitim öğretim yılında bir devlet üniversitesinin eğitim fakültesinde Okul Öncesi Eğitim Öğretmenliği, Türkçe Öğretmenliği ve Fen Bilimleri Öğretmenliği ana bilim dallarında öğrenim görmekte olan ve öğretmenlik uygulaması dersini alan 88 öğretmen adayı araştırmanın çalışma grubunu oluşturmuştur.

Çalışma grubu içerisindeki 20 öğretmen adayı Türkçe Öğretmenliği ana bilim dalında öğrenim görmektedir. Fen Bilimleri Öğretmenliği ana bilim dalından 23 öğretmen adayı ve Okul Öncesi Eğitim Öğretmenliği ana bilim dalından 45 öğretmen adayı araştırma sürecine katılım göstermiştir. Cinsiyete ilişkin belirlenen dağılım 78 kadın ve 10 erkekten oluşmakla birlikte öğretmen adaylarının 52'si 3. sınıf, 36'sı 4. sınıf düzeyinde öğrenim görmektedir.

\section{Veri Toplama Aracı}

Öğretmen profesyonelliğinin mesleğe özgü bakış açılarıyla incelendiği ve beceri, yeterlilik, gelişim boyutlarında ilişkisel bağlamların göz önünde bulundurularak öğretmen adaylarının süreç hakkında görüşlerin ele alındığı bu araştırmada yarı yapılandırılmış görüşme formu kullanılmıştır. Araştırmacılar tarafından hazırlanan görüşme formu; öğretmenlik mesleğine hazırlanan, bununla birlikte mesleki süreçlere yönelik uygulama boyutlarını gözlemleyebilme firsatı yakalayan katılımcılara yönelik oluşturulmuştur.

Yarı yapılandırılmış görüşme formu iki bölümden oluşmaktadır. İlk bölümde öğretmen adaylarına cinsiyet ve öğrenim görmekte oldukları bölümü belirtebilecekleri cevap alanı sunulmuştur. İkinci bölüm ise araştırmanın alt amaçları ile ilişkilendirilen 10 adet yarı yapılandırılmış açık uçlu sorudan oluşmaktadır. Form Okul Öncesi Öğretmenliği, Türkçe Öğretmenliği ve Fen Bilimleri Öğretmenliği bölümlerindeki alan uzmanlarına sunulmuştur. Ayrıca görüşme sorularının dil bilgisi açısından anlam ifadelerinin incelenebilmesi için aynı şekilde Türkçe Öğretmenliği alanında uzman bir öğretim üyesi tarafından incelenmiştir. Gelen dönütler çerçevesinde soruların kapsamı ve anlamsal biçimleri düzenlenmiştir.

Düzenlenen veri toplama aracı ile birlikte "Çanakkale Onsekiz Mart Üniversitesi Rektörlüğü Lisansüstü Eğitim Enstitüsü Etik Kurulu" adlı kuruma etik kurul izni için başvuru yapılmıştır. 08.04.2021 tarih ve 07/23 sayılı karar ile araştırmanın bilimsel araştırma etik kurul ilkelerine uygun olduğu belirlenmiştir.

\section{Geçerlik ve Güvenirlik Süreçleri}

Nitel araştırma yöntemiyle ele alınan çalışmalarda geçerlik ve güvenirlik süreçleri inandırıcılık, aktarılabilirlik, güvenirlik ve onaylanabilirlik boyutları çerçevesinde şekillendirilmektedir. Bu noktadan hareketle iç geçerlilik, dış geçerlilik ve güvenirliği sağlamak adına ifade edilen boyutlar dikkate alınarak uzun süreli etkileşim, katılımcı teyidi, uygun çalışma grubu seçimi, literatür ilişkisi çalışmaları gerçekleştirilmiştir. Ayrıca veri toplama aracının oluşturulması ve veri analizi aşamalarında uzman görüşlerinden yararlanılarak iç geçerlik ve güvenirlik yapıları desteklenmiştir (Yıldırım ve Şimşek, 2016).

Düzenlenen görüşme formuna ilişkin temel yanıt çerçevelerinin ve sorular arası ilişkili boyutların veri toplama süreci öncesi incelenebilmesi ve bu doğrultuda veri toplama aracının şekillendirilebilmesi için pilot çalışma gerçekleştirilmiştir. Bu aşamada belirlenen lisans eğitim programlarında öğrenim görmekte olan 15 öğrenciye çevirimiçi ortamdan görüşme formu ulaştırılarak yazılı görüşleri toplanmıştır. Gelen dönütler çerçevesinde uzman görüşleri doğrultusunda anlamsal ifadeler tekrar düzenlenmiş ve sorular genel çerçeveden özel boyutlara olacak şekilde sıralanmıştır. Pilot uygulamadan gelen yanıtlara göre taslak halinde alt temalar oluşturulmuş, bu ifadelerin ana temalar ile ilişkisi incelenmiştir.

\section{Veri Toplama}

Araştırmanın veri toplama aşamasında araştırmacılar tarafından hazırlanan pilot uygulama yapılan ve uzman görüşleri alınan görüşme formu çalışma grubunda belirlenen bölümlerde öğrenim görmekte olan ve öğretmenlik uygulamasını almış olan katılımcılara Google Formlar aracılığıyla ulaştırılmıştır. Bu süreçte katılımcılar görüşme formunda yer alan açık uçlu 10 soruyu yazılı halde cevaplandırarak sürece katılım sağlamışlardır. Bununla birlikte katılımcıların isimleri gizli tutularak her bir katılımcı için sıra gözetmeksizin kodlar belirlenmiş ve bu kodlar yardımıyla her tema için görüş 
belirten öğretmen adayı sayısı belirlenmiştir. Ayrıca kodlarla ilişkili olarak temalarda öne çıkan alt boyut ifadeleri doğrudan alıntı şeklinde alt bulgu başlıklarında sunulmuştur.

\section{Veri Analizi}

Yarı yapılandırılmış görüşme yoluyla toplanan veriler içerik analizi tekniği ile çözümlenmiştir. Bu aşamada araştırmanın alt amaçlarıyla ilişkili olacak şekilde ana temalar ve görüşlere bağlı olarak alt temalar oluşturulmuştur. Ardından oluşturulan ana tema ve alt temalar katılımcı görüşleriyle birlikte tekrar uzmanlara sunularak temaların görüşleri karşılama durumları incelenmiştir.

Analiz aşamasında MAXQDA 2020 paket programı kullanılarak sistematik kodlamalar yapılmış, veriler arası ilişki kaybı en az düzeye indirgenmiştir. Çalışma grubundaki toplam katılımcı sayısı 88 öğretmen adayından oluşmuş, her katılımcı tüm soruları yanıtlayarak görüşme sürecini tamamlamıştır. Bununla birlikte katılımcıların her soruda birden fazla alt boyuta ilişkin değerlendirme yapmaları ana temaların toplam frekans değerlerini etkilemiştir. Bulgularda sunulan toplam frekans değerleri temalara yönelik toplam görüş sayısını temsil etmektedir.

\section{Araştırmacının Rolü}

Geleneksel yaklaşıma dayalı olan araştırmacı rolünün aksine nitel yöntemin izlendiği araştırma süreçlerinde katılımcıların deneyimleri, bakış açıları dikkate alınarak kuramsal boyutta tartışmalar ortaya koyulabilmektedir. Elde edilen araştırma verilerinden hareketle veri toplama araçları, analiz biçimi bir ölçüde araştırmacının rolünü ve bakış açısını yansıtmaktadır. Araştırmacı bu süreçte olgu ve olaylara dahil olarak öznel bakış açısı yürütmekve de söz konusu deneyimlere empatik yaklaşmaktadır. Gerçeklik tüm boyutlarıyla ele alınarak nesnelliğin aksine yeniden oluşturulmaktadır (Robson, 2017). Mevcut araştırmada öğretmen profesyonelliğine ilişkin değerlendirmeler katılımcıların eğitim - öğretim deneyimlerinden, sosyal süreç faaliyetlerinden yararlanılarak elde edilmiş ve yorumlanmıştır.

\section{Bulgular}

Profesyonellik kavramının öğretmenlik mesleği açısından incelendiği araştırmada profesyonellik ile ilişkili 10 farklı ana tema araştırmanın alt bulgularını oluşturmaktadır. $\mathrm{Bu}$ ana temalar çerçevesinde görüşlere dayalı olarak belirlenen alt temaların ifade edilme düzeyleri sayısal ifadelerle sunulmuştur.

\section{Profesyonel Kişi Özellikleri Ana Temasına İlişkin Bulgular}

Öğretmen adaylarının profesyonellik kavramı ve profesyonel kişiyi tanımlama boyutunda belirtmiş olduğu görüşler "Profesyonel Kişi Özellikleri”" şeklinde belirlenen ana kategori altında toplanmıştır. Sorulara yönelik cevapların incelenmesi sonucu bu kapsamda belirlenen alt temalar, görüşleri ifade eden frekans ve yüzde değerleri Tablo 1'deki gibidir:

Tablo 1. Profesyonel kişi özellikleri ana temasına ilişkin kategori istatistikleri

\begin{tabular}{lll}
\hline Profesyonel Kişi Özellikleri & f & \% \\
\hline Alanda Gelişmek/Uzmanlaşmak & 44 & 32,84 \\
Mesleki Yeterlilik Sahibi & 21 & 15,67 \\
Bilgi/Donanım Sahibi & 20 & 14,93 \\
Duyuşsal/Düşünümsel Süreçleri Düzenlemek & 9 & 6,72 \\
Sorumluluk Sahibi & 6 & 4,48 \\
Mükemmel & 5 & 3,73 \\
Deneyimli & 5 & 3,73 \\
Yaratıci/Pratik & 3 & 2,24 \\
Aktarabilme Yetisine Sahip & 3 & 2,24 \\
Tarafsiz & 3 & 2,24 \\
Mevcut Koşullara Uyum Sağlamak & 2 & 1,49 \\
Etik İlkelere Sahip & 2 & 1,49 \\
\hline
\end{tabular}




\begin{tabular}{lcc}
\hline Çözüm/Süreç Odaklı & 2 & 1,49 \\
Doğru Karar Verebilen & 2 & 1,49 \\
Planlı & 1 & 0,75 \\
Değişim ve Yeniliğe Açık & 1 & 0,75 \\
Yetenekli & 1 & 0,75 \\
Çözüm Odaklı & 1 & 0,75 \\
Azimli & 1 & 0,75 \\
Özgüven Sahibi & 1 & 0,75 \\
Rol/Model & 1 & 0,75 \\
Toplam & $\mathbf{1 3 4}$ & $\mathbf{1 0 0}$ \\
\hline
\end{tabular}

Tablo 1 incelendiğinde "Profesyonel Kişi Özellikleri" ana teması ile ilişkilendirilen toplam 21 alt temanın bulunduğu görülmektedir. Öğretmen adaylarının profesyonellik kavramını açıkladığı ve profesyonel kişilere ilişkin tanımlamalar yaptığı görüşler incelendiğinde belirlenen boyutlar arasından sıklıkla "Alanda Gelişmek/Uzmanlaşmak" alt temasına değinildiği görülmektedir. Yoğun olarak ifade edilen diğer özellikler incelendiğinde öğretmen adayları; profesyonel kişilerin mesleki yeterliliğe, bilgi ve donanıma, duyuşsal ve düşünümsel süreçleri düzenleme becerilerine sahip olması gerektiği üzerine vurgu yapmıştır.

Öğretmen adaylarının bu tema içerisinde öne çıkan “Alanda Gelişmek/Uzmanlaşmak” alt boyutuna ilişkin görüşlerinden bazıları şu şekildedir:

"K50: Kendini geliştirmeyi seven insandır. Alanına ait bilgileri sürekli araştıran geliştiren kişidir. Karakterinde sevgiyi bilgiyi barındıran insandır."

"K15: Profesyonellik işi en iyi şekilde bilen olmanın yanı sıra o işi doğru, dürüst, ustaca ve kendine güvenerek yapmaktır. Profesyonel kişiler işini bu şekilde yapabilen, bunu başarabilendir. Sürekli öğrenmeye ve gelişmeye açıktır, azimlidir."

Sıklıkla ifade edilen "Mesleki Yeterlilik Sahibi” alt boyutuna ilişkin görüşlerden bazıları şu şekildedir:

"K58: Bir işi en iyi şekilde yapmak. Benim için görevini zamanında yerine getiren gereken bilgi ve donanıma sahip olmaktır."

"K41: Profesyonellik, bir alana ilişkin sahip olunan bilgi, beceri ve sorumlulukları kapsar. Profesyonel kişi de mesleğinin getirmiş olduğu yükümlülükleri yerine getirendir."

Bu özellikler çerçevesinde "Bilgi/Donanım Sahibi” alt boyutuna ilişkin görüşlerden bazıları şu şekildedir:

"K61: Herhangi bir alanda bir kişinin her türlü bilgiye sahip olmasıdır."

"K30: İşinde başarılı bir rol model olması. Bana göre profesyonel iletişimi iyi olan karşısındakine saygı duyan ve işinde belki birikim bilgi ve donanıma sahip olandır.”

\section{Mesleki Profesyonellik Ana Temasına İlişsin Bulgular}

Öğretmen adaylarının profesyonellik mesleki açıdan değerlendirdiği görüşler "Mesleki Profesyonellik" şeklinde belirlenen ana kategori altında toplanmıştır. Sorulara yönelik cevapların incelenmesi sonucu bu kapsamda belirlenen alt temalar, görüşleri ifade eden frekans ve yüzde değerleri Tablo 2'deki gibidir:

Tablo 2 Mesleki profesyonellik ana temasına ilişkin kategori istatistikleri

\begin{tabular}{lll}
\hline Mesleki Profesyonellik & f & \% \\
\hline İdeal Niteliklerle Çalışmak & 28 & 20,44 \\
Alanda Uzmanlık & 20 & 14,60 \\
\hline
\end{tabular}




\begin{tabular}{lll}
\hline Bilgili Olmak & 15 & 10,95 \\
Gelişime/Yeniliğe Açık Olmak & 14 & 10,22 \\
Başarılı Olmak & 11 & 8,03 \\
Deneyim Sahibi & 9 & 6,57 \\
Performansı/Bilgiyi Aktarabilmek & 6 & 4,38 \\
Mantığa Dayalı Çalışmak & 6 & 4,38 \\
Özverili/Saygılı Olmak & 4 & 2,92 \\
Duyuşsal Hazır Oluş & 3 & 2,19 \\
Sorumluluk Sahibi Olmak & 3 & 2,19 \\
Güncelliği Takip Etmek & 3 & 2,19 \\
Pratik Olmak & 2 & 1,46 \\
Hedef Belirlemek/Gerçekleştirmek & 2 & 1,46 \\
Lider & 2 & 1,46 \\
Eşit/Rasyonel Bakış Açısı & 2 & 1,46 \\
Alanda Standartlaşmak & 2 & 1,46 \\
Fırsat/Koşul İlişkisi Kurmak & 1 & 0,73 \\
Uygulayıcı & 1 & 0,73 \\
Çözüm Odaklı & 1 & 0,73 \\
Mesleki Doyuma Ulaşmak & 1 & 0,73 \\
Stresi Yönetebilmek & 1 & 0,73 \\
Toplam & $\mathbf{1 3 7}$ \\
\hline
\end{tabular}

Tablo 2 incelendiğinde "Mesleki Profesyonellik" ana teması ile ilişkilendirilen toplam 22 alt temanın bulunduğu görülmektedir. Öğretmen adaylarının profesyonelliği mesleki açıdan değerlendirdiği görüşler incelendiğinde belirlenen boyutlar arasından sıklıkla "İdeal Niteliklerle Çalışmak" alt teması kapsamında görüş belirtildiği görülmektedir. Yoğun olarak ifade edilen diğer özellikler incelendiğinde öğretmen adaylarının mesleki profesyonelliği alanda uzmanlık çerçevesinde değerlendirdiği, bilgili olma ile ilişkilendirdiği, kişisel gelişim ve yeniliğe açık olma boyutlarında ele aldığ 1 belirlenmiştir.

Öğretmen adaylarının bu tema içerisinde öne çıkan "İdeal Niteliklerle Çalışmak" alt boyutuna ilişkin görüşlerinden bazıları şu şekildedir:

“K38: Meslekte profesyonel olma mesleğinin gerektirdiği özelliklere uygun olarak davranma olabilir."

“K74: Mesleğine yönelik her konuda başarılı olmak ve mesleğinin gerektirdiği özelliklere sahip olmaktır. Örnekle açıklayacak olursak; bir doktor mesleğinde profesyonel olmak için öncellikle altı ylllık eğitim sürecinden geçmeli daha sonra meslek hayatına atıldı̆̆ında sürekli araş̧ırmacı olmalıdır. Sadece bunlarda yeterli olmayacaktır. Ayrıca doktor hastalartyla iliş̧kilerinde ne samimi ne de soğuk davranmalıdır. Zira mesleki hayatta profesyonel olan kişiler nerede ne zaman nasıl davranacaklarını bilen kimselerdir. Aniden çıkan sorunlara pratik şekilde çözüm bulabilen kişiler mesleklerinde profesyonel olmuşlar demektir."

Sıklıkla ifade edilen "Alanda Uzmanlık” alt boyutuna ilişkin görüşlerden bazıları şu şekildedir:

"K6: Meslek için belli bir eğitim alıp o meslekte ilerlemek o işin uzmanı olmak"

"K15: Ĕ̆itimini aldı̆̆ bir işi yaparken o işte, o meslekte uzmanlaşmayl, dürüst olmayı ve hakkını vererek yapmayı başarabilmektir. Mesleğini, kendisini gelişstirmeye ve ilerlmeye azmederek sürdürmektir."

Teorik birikim ile ilişkilendirilen "Bilgi Olmak" alt boyutuna ilişsin görüşlerden bazıları şu şekildedir: 
"K16: Mesleğinin gerektidiği Kriterlere uygun bilgi ve donanım sahibi olmaktır.”

"K36: Bilgi, beceri, pratik, tecrübe açısından açısından yeterli donanıma sahip olmak."

\section{Öğretmenlik Mesleği Özellikleri Ana Temasına İlişkin Bulgular}

Öğretmen adaylarının öğretmenlik mesleğini değerlendirdiği görüşler “Öğretmenlik Mesleği Özellikleri” şeklinde belirlenen ana kategori altında toplanmıştır. Sorulara yönelik cevapların incelenmesi sonucu bu kapsamda belirlenen alt temalar, görüşleri ifade eden frekans ve yüzde değerleri Tablo 3'teki gibidir:

Tablo 3. Öğretmenlik mesleği özellikleri ana temasına ilişkin kategori istatistikleri

\begin{tabular}{lll}
\hline Öğretmenlik Mesleği Özellikleri & f & \% \\
\hline Geleceği İnşa Etmek & 24 & 17,78 \\
Temel Meslek & 18 & 13,33 \\
Sabırlı/Hoşgörülü Olmak & 12 & 8,89 \\
Rehber/Model Olmak & 11 & 8,15 \\
Koşulsuz Sevgi & 10 & 7,41 \\
Maneviyat/Duygu Sahibi Olmak & 9 & 6,67 \\
Doğrudan Etki Sahibi & 8 & 5,93 \\
Çok Yönlü Olmak & 8 & 5,93 \\
Gelişime Açı Olmak & 5 & 3,70 \\
İnsan İlişkilerine Dayalı Olmak & 5 & 3,70 \\
İletişim Becerilerine Sahip & 5 & 3,70 \\
Fırsat Sunmak & 5 & 3,70 \\
Fayda Sağlamak & 4 & 2,96 \\
Sorumluluk Sahibi Olmak & 4 & 2,22 \\
Eşgüdümlü Olabilmek & 3 & 2,22 \\
Tecrübeli Olmak & 3 & 0,74 \\
Gönüllü Olmak & 1 & 0,74 \\
Statü Sahibi Olmak & 1 & 0,74 \\
Fedakar Olmak & 1 & 0,74 \\
Etik İlkeleri Benimsemek & 1 & 0,74 \\
Toplam & 1 & $\mathbf{1 0 0}$ \\
\hline
\end{tabular}

Tablo 3 incelendiğinde "Öğretmenlik Mesleği Özellikleri” ana teması ile ilişkilendirilen toplam 20 alt temanın bulunduğu görülmektedir. Öğretmenlerin sahip olması gereken özelliklerin tanımlandığı görüşler incelendiğinde belirlenen boyutlar arasından sıklıkla "Geleceği İnşa Etmek" alt teması kapsamında ifadelere yer verdiği görülmektedir. Diğer ifadeler incelendiğinde öğretmen adayının bu özellikleri temel meslek bağlamında değerlendirdiği, özellikler arasında sabırlı ve hoşgörülü olma boyutlarına değinildiği, öğretmenin rehber ve model olarak vurgulandığ 1 belirlenmiştir.

Öğretmen adaylarının bu tema içerisinde öne çıkan "Geleceği İnşa Etmek” alt boyutuna ilişkin görüşlerinden bazıları şu şekildedir:

"K15: Ö̆̆retmen bir çocuğa değil bir nesle eğitim verir, öğretim să̆lar. Kişilik gelişiminde neredeyse aileden daha çok ögretmeniyle zaman geçirmekte olan çocuklar için öğretmenler en büyük rol modelidir. Benim için öğretmenliği diğer mesleklerden ayıran en büyük özellik ögretmenin çocuğun ailesinden birisi haline gelmesidir. O bir meslek olmanın 
yanı sıra kan bağı olmasa da ögrenci ve ailesiyle bağlanmasıdır. Öğretmen kuşakların geri veya ileri gitmesini sağlayan ince bir çizgidir."

"K73: Öğretmenler, insan yetiştirir. Gelecek nesilleri iyi, ahlâkll bir şekilde yetiştirmek ögretmenin en önemli görevlerindendir. Bu yönüyle diğer mesleklerden ayrılır."

Sıklıkla ifade edilen "Temel Meslek" alt boyutuna ilişkin görüşlerden bazıları şu şekildedir:

"K82: Bütün mesleklerin yetiştiricisi olması ve bunun sorumluluğunu üstlenmesi, Toplumun iyi yönde gelişebilmesi ve aydınlanmanın sağlanması açısından geleceğin bireylerini yetiştirmesi, İçinde insan sevgisini en çok taşıyan meslek olmadır."

"K79: Öncelikle bütün mesleklerin oluşumuna katkıda bulunan kişi öğretmenlerdir. Öğrenciyi hayata, mesleğe hazırlayanlardır. Küçük yaştan itibaren bireyin hayatında olup gelişiminde olumlu ve olumsuz önemli değişimlere yol açarlar."

Sosyal ilişkilerden söz edilen görüşlerde sıklıkla öne çıkan "Sabırl1/Hoşgörülü Olmak” alt boyutuna ilişkin görüşlerden bazıları şu şekildedir:

"K12: Sabır ve değişen topluma ayak uydurmaya çalışması gereken öğrencileri için her daim daha çok çalışan ve üretken olmaya çalışan bir meslek grubu olarak diğer meslek gruplarından ayrllabilir."

"K20: Daha sabırlı olmayi gerektirir, insanlara insan olduklari icin deger vermesi gerektiğini bilir öğretmen, çocukları sever vs."

\section{Profesyonel Öğretmen Özellikleri Ana Temasına İlişkin Bulgular}

Öğretmen adaylarının öğretmenlik mesleğini profesyonellik olgusuna bağlı olarak değerlendirdiği görüşler "Profesyonel Öğretmen Özellikleri” şeklinde belirlenen ana kategori altında toplanmıştır. Sorulara yönelik cevapların incelenmesi sonucu bu kapsamda belirlenen alt temalar, görüşleri ifade eden frekans ve yüzde değerleri Tablo 4'teki gibidir:

Tablo 4. Profesyonel öğretmen özellikleri ana temasına ilişkin kategori istatistikleri

\begin{tabular}{lll}
\hline Profesyonel Öğretmen Özellikleri & f & \% \\
\hline Gelişime/Yeniliğe Açık Olmak & 41 & 16,47 \\
Mesleki Yeterliliğe Sahip & 19 & 7,63 \\
İletişim Becerilerine Sahip & 18 & 7,23 \\
Alanda Uzman & 16 & 6,43 \\
Hoşgörülü/Merhametli/Sevecen & 13 & 5,22 \\
Öz Yeterliliklere Sahip & 12 & 4,82 \\
Sabırlı & 11 & 4,42 \\
Demokratik/Etik & 10 & 4,02 \\
Çok Yönlü Aktarım Sağlayan & 10 & 4,02 \\
Eşitlikçi/Denge Sağlayabilen & 8 & 3,21 \\
Donanımlı & 8 & 3,21 \\
Çözüm Odaklı & 8 & 3,21 \\
Sosyal/Dışadönük & 7 & 2,81 \\
Aktif/Üretken & 6 & 2,41 \\
Özgün/Yaratıcı & 6 & 2,41 \\
Rehber Olan & 6 & 2,41 \\
Planlı & 5 & 2,01 \\
\hline
\end{tabular}




\begin{tabular}{lll}
\hline Lider Ruhlu & 5 & 2,01 \\
Standartlara Uyan & 5 & 2,01 \\
Öğrenci Merkezli & 5 & 2,01 \\
Sorumluluk Sahibi & 5 & 2,01 \\
Soğukkanlı & 4 & 1,61 \\
Deneyimli & 4 & 1,61 \\
Sağduyulu & 3 & 1,20 \\
Karar/Yönetim Becerilerine Sahip & 3 & 1,20 \\
Özverili & 3 & 1,20 \\
Objektif & 3 & 0,80 \\
İşbirlikçi/Paylaşımcı & 2 & 0,80 \\
Çocuk Ruhlu & 2 & 0,40 \\
Analiz Yapabilen & 2 & 0,40 \\
Başarılı & 1 & 0,40 \\
Pratik & 1 & 0,40 \\
Toplam & 1 & $\mathbf{1 0 0}$ \\
\hline
\end{tabular}

Tablo 4 incelendiğinde "Profesyonel Öğretmen Özellikleri” ana teması ile ilişkilendirilen toplam 32 alt temanın bulunduğu görülmektedir. Profesyonellik ve öğretmenlik özelliklerinin ilişkili halde sunulduğu görüşler incelendiğinde belirlenen boyutlar arasından sıklıkla "Gelişime/Yeniliğe Açık Olmak" alt temasına yönelik vurgu yapıldığı görülmektedir. Diğer ifadeler incelendiğinde öğretmen adayları bu özellikleri mesleki mesleki yeterliliğe ve iletişim becerilerine sahip olma, alanda uzman olma boyutlarıla ilişkilendirmiştir.

Öğretmen adaylarının bu tema içerisinde öne çıkan "Gelişime/Yeniliğe Açık” alt boyutuna ilişkin görüşlerinden bazıları şu şekildedir:

"K15: Öğremenler öncelikle çağına ve gelişen teknolojiye ayak uydurabilmelidir. Bunun yanı sıra sürekli araştıran, ögretirken ögrenen olmalıdır. Peki kendisi ögrrendiyse bunları çocuklara nasıl aktarmalıdır? İşte profesyonel ögretmen; bulunduğu çevrede ve sinıftaki ögrencilerine kendi ögrendiklerini hangi yolla iyi ögretebileceğini de bilen ve doğru aktarım yapabilen ögretmendir."

"K41: Profesyonel ögrretmen yeniliklere, eleştirilere açıktır. Hata yaptığında öfkelenmek veya inkar etmek yerine, hatasını düzeltmeye çalışır. Kendini sürekli gözlemler."

Benzer şekilde sıklıkla ifade edilen "Mesleki Yeterliliğe Sahip" alt boyutuna ilişkin görüşlerden bazıları şu şekildedir:

"K26: Çocuğun eğitimini de en az öğretim kadar önemseyen, yaşanabilecek olumsuz durumlar karşısında soğuk kanlı olup anında çözüm üretebilen, mesleki anlamda yeterliliğe kavuşmuş, öğrencilerin yalnızca dersle alakalı değil kişisel sorunlartyla da alakadar olabilen."

“K21: Öğretmenlik mesleğinin gerektirdiği bilgi,beceri, tutum alanında en iyisi olmadır.”

Sıklıkla ifade edilen "İletişim Becerilerine Sahip” alt boyutuna ilişkin görüşlerden bazıları şu şekildedir:

"K5: Empati yeteneği gelişmiş İyi iletişim kuran Merhametli olan Öğrenci dilinden anlayan Kendisinin de bir zamanlar öğrenci olduğunu unutmayan Bilgilerini tam anlamıyla öğrencilerine aktarmaya çalışan."

"K16: Meslek gereği çocuklarla sürekli bir iletişim içindeyiz.Bu yüzden öğretmenin empati ve eşitlikçi bir yaklaşım içinde olmalıdir." 


\section{Profesyonel Gelişim Bileşenleri Ana Temasına İlişkin Bulgular}

Öğretmen adaylarının profesyonel gelişimi oluşturan bileşenleri tanımladığı görüşler "Profesyonel Gelişim Bileşenleri”" şeklinde belirlenen ana kategori altında toplanmıştır. Sorulara yönelik cevapların incelenmesi sonucu bu kapsamda belirlenen alt temalar, görüşleri ifade eden frekans ve yüzde değerleri Tablo 5’teki gibidir:

Tablo 5. Profesyonel gelişim bileşenleri ana temasına ilişkin kategori istatistikleri

\begin{tabular}{|c|c|c|}
\hline Profesyonel Gelişim Bileşenleri & f & $\%$ \\
\hline Eğitsel Toplantılar/Kurslar & 26 & 15,76 \\
\hline Deneyim & 21 & 12,73 \\
\hline Ortam Düzenlemeleri & 20 & 12,12 \\
\hline Kişisel Gelişim & 19 & 11,52 \\
\hline Araştırma Yapma & 16 & 9,70 \\
\hline Güncel İçerikleri & 10 & 6,06 \\
\hline Duyarlı/İstekli Tutum Geliştirmek & 10 & 6,06 \\
\hline Sürekli Gelişim & 8 & 4,85 \\
\hline Uygulama Ağırlıklı Ders İçerikleri & 7 & 4,24 \\
\hline İş birliği Kurmak & 4 & 2,42 \\
\hline Değerlendirme Süreçleri & 4 & 2,42 \\
\hline Kriz Yönetimi & 3 & 1,82 \\
\hline Özgür Bakış Açısı & 3 & 1,82 \\
\hline Projelerde Yer Alma & 2 & 1,21 \\
\hline Plan Yapma & 2 & 1,21 \\
\hline Yetenek & 2 & 1,21 \\
\hline İmkan Kullanımı & 1 & 0,61 \\
\hline Ders İçeriği Denetlemeleri & 1 & 0,61 \\
\hline Demokratik/Dengeli Tutum & 1 & 0,61 \\
\hline Görev Çeşitliliği & 1 & 0,61 \\
\hline Sosyal Yaşantı & 1 & 0,61 \\
\hline Mesleğe Odaklanma & 1 & 0,61 \\
\hline Teorik Bilgi & 1 & 0,61 \\
\hline Kaliteli Eğitim & 1 & 0,61 \\
\hline Toplam & 165 & 100 \\
\hline
\end{tabular}

Tablo 5 incelendiğinde "Profesyonel Gelişim Bileşenleri" ana teması ile ilişkilendirilen toplam 24 alt temanın bulunduğu görülmektedir. Öğretmen adaylarının profesyonel gelişime öncülük eden yapıları ifade ettiği görüşler incelendiğinde belirlenen boyutlar arasında sıklıkla "Eğitsel Toplantılar/Kurslar" kapsamında ifadelerin yoğunlaştı̆̆1 görülmektedir. Belirtilen diğer alt temalar incelendiğinde öğretmen adayının bu bileşenler arasında deneyimi, ortam düzenlemelerini, kişisel gelişimi vurguladığı belirlenmiştir.

Öğretmen adaylarının bu tema içerisinde öne çıkan "Eğitsel Toplantılar/Kurslar" alt boyutuna ilişkin görüşlerinden bazıları şu şekildedir:

“K60: Öğretmeni geliştirmeye yönelik yapılan seminerlerle konferanslarla desteklenebilir." 
“K88: Yaşanabilecek her türlü kriz anı öğretmene kriz yönetimi açısından deneyim kazandırmış olur böylece kriz anında yapılması gerekenler ögrenilmiş ve profesyonelleşme sürecinde önemli bir adım atılmış olur. Ayrıca ögretmenin kendi alanında yaptı̆̆l çeşitli araştırmalar, katıldiğg seminerler ve kendini geliştirme girişimleri profesyonel anlamda gelişmeye katkı sağlar."

Sıklıkla ifade edilen "Deneyim" alt boyutuna ilişkin görüşlerden bazıları şu şekildedir:

“K25: Öğretmenlik ĕ̆itimi sırasında öğretmen adaylarının, farklı sosyoekonomik düzeydeki, farkl yerleşim yerlerinde vb. Olabildiğince farkll yerlerde staj yaparak tecrübe kazanması ile desteklenmelidir."

"K36: Staj çalışmaları ile teorideki bilgi pratiğe dökülerek tecrübe vasıtası ile bu konuda ilk adımlar atılabilir"

Çevre şartlarının değerlendirildiği “Ortam Düzenlemeleri” alt boyutuna ilişkin görüşlerden bazıları şu şekildedir:

"K12: Ö̆̆retmene zengin uyarıcı ortamı ve gerekli imkan dahilinde ve öğretmenin öğrenme hevesi ile gelişme sağlanabilir."

"K24: Kaliteli egitim, deneyimler, kisisel caba ile kisisel gelisim, serbest fikir ortami, her yonden yeterli hale getirilmeye calisilan bir cevre"

\section{Etkili Öğretmen Özellikleri Ana Temasına İlişkin Bulgular}

Öğretmen adaylarının etkili öğretmenlerin sahip olması gereken özellikleri ifade ettiği boyutlar "Etkili Öğretmen Özellikleri" şeklinde belirlenen ana tema altında toplanmıştır. Sorulara yönelik cevapların incelenmesi sonucu bu kapsamda belirlenen alt temalar, görüşleri ifade eden frekans ve yüzde değerleri Tablo 6'daki gibidir:

Tablo 6. Etkili öğretmen özellikleri ana temasına ilişkin kategori istatistikleri

\begin{tabular}{lll}
\hline Etkili Öğretmen Özellikleri & f & \% \\
\hline İletişim Becerilerine Sahip & 25 & 16,03 \\
Sosyal Becerilere Sahip & 19 & 12,18 \\
Gelişime/Yeniliğe Açık & 16 & 10,26 \\
Rehber/Model & 13 & 8,33 \\
Anlayışl//Sabırlı & 11 & 7,05 \\
Ortam/Zaman Kontrolü Sağlayabilen & 8 & 5,13 \\
Öğrenciyi Merkeze Alan & 7 & 4,49 \\
Bireysel Farklılıkları Dikkate Alan & 7 & 4,49 \\
Esnek & 6 & 3,85 \\
İlgi/İstek Sahibi & 6 & 3,85 \\
Farklı Yöntem/Teknik Kullanabilen & 5 & 3,21 \\
Araştırmacı & 4 & 2,56 \\
Aktif & 3 & 1,92 \\
Demokratik & 3 & 1,92 \\
Çözüm Odaklı & 3 & 1,92 \\
Değerlendirmeye Açık & 3 & 1,92 \\
Deneyimli & 3 & 1,92 \\
Girişimci/Lider & 3 & 1,28 \\
Motive Olabilen/Edebilen & 2 & 1,28 \\
Öz Yönetim Becerilerine Sahip & 2 & 1,28 \\
\hline
\end{tabular}




\begin{tabular}{llc}
\hline Çok Yönlü Gelişim & 2 & 1,28 \\
Yaratıcı & 2 & 1,28 \\
Öğretim Becerilerine Sahip & 2 & 1,28 \\
Bilgi Sahibi & 1 & 0,64 \\
Bilinçli & 1 & 0,64 \\
Toplam & $\mathbf{1 5 6}$ & $\mathbf{1 0 0}$ \\
\hline
\end{tabular}

Tablo 6 incelendiğinde "Etkili Öğretmen Özellikleri” ana teması ile ilişkilendirilen toplam 26 alt temanın bulunduğu görülmektedir. Öğretmen adaylarının öğretmenlerin etkili öğretmen özelliklerini oluşturan yapıları ifade ettiği görüşler incelendiğinde belirlenen boyutlar arasından sıklıkla "İletişim Becerilerine Sahip" alt teması kapsamında ifadelerin yoğunlaştığı görülmektedir. Bu öğretmenlerin sahip olması gereken özelliklere ilişkin belirtilen diğer alt temalar incelendiğinde etkili öğretmen nitelikleri sosyal becerilere sahip olma, gelişime ve yeniliğe açık olma, rehber ve model olma şeklinde ele alınmıştır.

Öğretmen adaylarının bu tema içerisinde öne çıkan "İletişim Becerilerine Sahip” alt boyutuna ilişkin görüşlerinden bazıları şu şekildedir:

"K6: Sosyal aktivitelerde yer alan, çocuklarla iletişim becerisini geliştirmeye odaklanan, eleştirel bir dil kullanmak yerine empatik dil kullanmayı tercih eden ögretmen etkili olacaktır."

"K84: - Etkili bir öğretmenin ögrrencileriyle iletişimi kuvvetli olmalıdır. Öğrencilerini motive etmeli ve enerjik olmalıdır. - Öğrencilerine karşı saygıll, dürüst, hoşgörülü, güler yüzlü olmalıdır. - Öğrencilerine karşı anlaylşlı olmalı ve sorunlarına çözüm bulmak için yardımcı olmalıdır. - Gerek davranışları gerek giyim kuşamı gerekse konuşma tarzı ve üslubuyla ögrencilerine rol model olmalıdır. - Her zaman öğrencilerinin faydasını düşünerek kendi gelişstirmeye açık olmalıdır."

Sıklıkla ifade edilen "Sosyal Becerilere Sahip” alt boyutuna ilişkin görüşlerden bazıları şu şekildedir:

"K50: Sosyal çevresi iyi olan, iletişim halinde olmayı seven, gezip görmeyi araştırı incelemeyi seven ögretmenler olmalıdır.. sosyal yaşantısı kötü olan ögretmenler her ne olursa olsun bunu ögrencilerine yansitırlar. Bu yüzden herkesin ögretmen olmaması gerektiğini, bunun için her senede bir tüm ögrretmenlere belli çalışmalar veya tespit sinavlarl yaptırllması gerektiğini düşünüyorum."

"K18: Sosyal yaşantımızda bile bir tarafımız ögretmen aslında. Çocuklara rol model olmak açısından bu çok önemli. Hayatın her alanında öğretmenlik mesleğine uygun davranılmalı"

Diğer ana temalarda da öne çıkan "Gelişime/Yeniliğe Açık" alt boyutuna ilişkin görüşlerden bazıları şu şekildedir:

"K16: Günümüzde her şey çok hızlı gelişip değişmekte çocuklarda bu değişimin içinde olduklarından hayatlarını etkilemektedir. Bir ögretmenin bütün bunların farkında olarak kendini geliştirmesi gerekir.”

"K82: Dünya geneline bakıldiğında eğitimin sadece okullarla sinırlandırılmadı̆̆ı, yaşam boyu öğrenmenin ne denli önem arz ettiği ortadadır. Bu sebeple ögretmenlik mesleği okul kademeleriyle ve ders süreleriyle sinırlandırllmamall, ögretmenlerin faydalı olabileceği her türlü kurum ve kuruluşlarda yetenekleri doğrultusunda görev alması, mesleki açıdan kendisine katkı sağlayabileceği eğitimlere katılması gerekmektedir. Eğitimin gizil işlevlerinden biri bireyin sosyalleşmesine katkı sağlamasıdır. Böylece çift yönlü etkileşim gerçekleşmiş olup hem toplumun aydınlanması hem de donanım açısından öğretmenlerin yetkinliği artacaktır."

\section{Mesleki Süreç ve İşbirliği İlişkisi Ana Temasına İlişkin Bulgular}

Öğretmen adaylarının öğretmenlik mesleği süreci ve bu süreçte kurulabilecek işbirliğine dayalı ifade ettiği boyutlar "Mesleki Süreç ve İşbirliği İlişkisi” şeklinde belirlenen ana tema altında toplanmıştır. Sorulara yönelik cevapların incelenmesi sonucu bu kapsamda belirlenen alt temalar, görüşleri ifade eden frekans ve yüzde değerleri Tablo 7'deki gibidir: 
Tablo 7. Mesleki süreç ve işbirliği ilişkisi ana temasına ilişkin kategori istatistikleri

\begin{tabular}{|c|c|c|}
\hline Mesleki Süreç ve İşbirliği İlişkisi & f & $\%$ \\
\hline Kişisel/Mesleki Gelişim & 11 & 10,58 \\
\hline Düşünme Becerilerinde Çeşitlilik & 11 & 10,58 \\
\hline Bilgi Çeşitliliği/Aktarımı & 10 & 9,62 \\
\hline İletişim & 10 & 9,62 \\
\hline Dayanışma/Uzlaşma & 8 & 7,69 \\
\hline Başarı/Verimlilik & 7 & 6,73 \\
\hline Ulaş1labilir Hedefler & 5 & 4,81 \\
\hline Sosyal Etkileşim & 4 & 3,85 \\
\hline Sorumluluk Bilinci & 4 & 3,85 \\
\hline Etkin Öğrenme Öğretme & 4 & 3,85 \\
\hline Çözüm Ortamları & 4 & 3,85 \\
\hline Yeni Keşifler & 3 & 2,88 \\
\hline Kaliteli eğitim & 3 & 2,88 \\
\hline Zaman Tasarrufu & 3 & 2,88 \\
\hline Karakter Tespiti & 3 & 2,88 \\
\hline Pedagojik Katkılar & 2 & 1,92 \\
\hline Grup Bağl1lı̆̆1 & 2 & 1,92 \\
\hline Kalıcı Davranış Oluşturma & 2 & 1,92 \\
\hline Profesyonelliğe/Mükemmelliğe Ulaşma & 1 & 0,96 \\
\hline Alanlar Arası Etkileşim & 1 & 0,96 \\
\hline Duygu Çeşitliliği & 1 & 0,96 \\
\hline Yenilik & 1 & 0,96 \\
\hline Rekabetsiz Ortam & 1 & 0,96 \\
\hline Etkin Katılım & 1 & 0,96 \\
\hline Olumlu Bağlılık & 1 & 0,96 \\
\hline Motivasyon & 1 & 0,96 \\
\hline Toplam & 104 & 100 \\
\hline
\end{tabular}

Tablo 7 incelendiğinde "Mesleki Süreç ve İşbirliği İlişkisi” ana teması ile ilişkilendirilen toplam 26 alt temanın bulunduğu görülmektedir. Öğretmen adaylarının mesleki süreçleri ve bu süreçte kurulabilecek işbirliği boyutları bağlamında ifadeleri incelendiğinde sıklıkla görüş belirtilen temaların "Kişisel/Mesleki Gelişim" ve "Düşünme Becerilerindeki Çeşitlilik" alt temaları olduğu görülmektedir. Bu süreç ve kurulabilecek işbirliği boyutuna ilişkin diğer alt temalar incelendiğinde öğretmen adayları; bilgi çeşitliliği ve aktarımıyla birlikte iletişimin güçleneceği, dayanışma ve uzlaşma sağlanacağı, başarı ve verimliliğin destekleneceği yönünde ifadeleri vurgulamıştır.

Öğretmen adaylarının bu tema içerisinde öne çıkan “Kişisel/Mesleki Gelişim” alt boyutuna ilişkin görüşlerinden bazıları şu şekildedir:

"K26: Kişiler arası iş birliği karşılıklı etkileşim sonucu iki bireyinde olumlu anlamda mesleki gelişim göstermelerini să̆lar." 
"K82: Öğretmenlik mesleği her ne kadar sınıf ortamı içerisinde diğer insanlardan yalıtılmış olsa da mesleki gelişim açısından en önemli destekleri meslektaşlarıdır. Bu yönüyle ögretmenlerin meslektaşlarıyla iş birliği içinde olmaları, onlara birbirlerinin deneyimlerinden faydalanma ve mesleki eksiklerini giderme ve kendilerini bilgi yönünden geliştirme firsatı sağlar."

Sıklıkla ifade edilen "Düşünme Becerilerinde Çeşitlilik" alt boyutuna ilişkin görüşlerden bazıları şu şekildedir:

"K43: Akll akıldan üstündür atasözünü referans alarak diyebiliriz ki bir öğretmenin düşünemediniz ya da yeterli olmadiğı konularda diğer meslektaşı daha yeterli olabilir"

"K16: Bazı şeylerde kendimizin üzerinde fazla yük ve sorumluluklar olabiliyor. Insanların bunu paylaşması biraz rahatlaması ve bunu getirdiği işbirlikçi ortamda daha fazla fikir ortamının genişlemesi katkı sağlayacaktır."

Öğretmenlerin sahip oldukları donanım ve aktarım durumlarını ifade ettiği "Bilgi Çeşitliliği/Aktarımı" alt boyutuna ilişkin görüşlerden bazıları şu şekildedir:

"K38: Her meslekte işbirliği çok önemlidir. Yönetici ve diğer insanlar arasında da iş arkadaşları arasında da işbirliği olması gerekiyor. Daha verimli bir çalışma hayatı olur. Az zamanda çok iş gerçekleşir."

"K72: Çözüm odaklı öğrenme ögretme ortamı oluşur. Akran ögrenmeleri aracıllı̆ıyla bilgi paylaşıllr ve büyür."

"İletişim” alt boyutuna ilişkin görüşlerden bazıları şu şekildedir:

"K15: İşbirliği olursa düzen olur. Düzen olursa sorunların en aza indiği bir meslek hayatı olur. Kişiler arası iletişim iyi olur ve böylelikle herkes kendi görev ve sorumluluklarınin bilinciyle hareket eder."

"K58: Öğrenci ve aile ile işbirliği içinde olmall. Okul yönetimiyle iş birliği içinde olunmal. Daha kolay süreç geçirmeye yardımcı olur. Etkili bir etkileşim olur."

\section{Öğretmenlik Mesleğinde Lisans Eğitiminin Etkisi Ana Temasına İlişkin Bulgular}

Öğretmen adaylarının almış oldukları lisans eğitiminin mesleki sürece etkisinin değerlendirildiği boyutlar "Öğretmenlik Mesleğinde Lisans Eğitiminin Etkisi” şeklinde belirlenen ana tema altında toplanmıştır. Sorulara yönelik cevapların incelenmesi sonucu bu kapsamda belirlenen alt temalar, görüşleri ifade eden frekans ve yüzde değerleri Tablo 8'deki gibidir:

Tablo 8. Öğretmenlik mesleğinde lisans eğitiminin etkisi ana temasına ilişkin kategori istatistikleri

\begin{tabular}{lll}
\hline Öğretmenlik Mesleğinde Lisans Eğitiminin Etkisi & f & \% \\
\hline Etkili & 41 & 52,56 \\
Kısmen Etkili & 33 & 42,31 \\
Etkili Değil & 4 & 5,13 \\
Toplam & $\mathbf{7 8}$ & $\mathbf{1 0 0}$ \\
\hline
\end{tabular}

Tablo 8 incelendiğinde "Öğretmenlik Mesleğinde Lisans Eğitiminin Etkisi” ana teması ile ilişkilendirilen toplam 3 alt temanın bulunduğu görülmektedir. Öğretmen adaylarının almış oldukları lisans eğitimiyle öğretmenlik mesleğini ilişkilendirdiği boyutlar incelendiğinde belirlenen 3 alt tema arasından ifadelerin yoğun olarak "Etkili" alt teması kapsamında toplandığ1 görülmektedir. Bu etkiye ilişkin diğer alt temalar incelendiğinde sıklıkla öğretmen adaylarının bu eğitimi kısmen etkili gördüğü, ancak az sayıda öğretmen adayının ise lisans eğitimini mesleki süreç boyutunda hiç etkili görmediği ifadelerine ulaşılmıştır. şekildedir:

Öğretmen adaylarının bu tema içerisinde öne çıkan "Etkili” alt boyutuna ilişkin görüşlerinden bazıları şu

"K2: Lisans eğitimi her döneminde etkili olur çünkü iyi alınmış lisans eğitimi, öğretmenin kendine nasıl bir yol çizeceği hakkında bir pusula görevi görür."

"K12: Lisans eğitimi her döneminde etkili olur çünkü iyi alınmış lisans eğitimi, öğretmenin kendine nasıl bir yol çizeceği hakkında bir pusula görevi görür.” 
"K36: Tamamında tabiki, sonuçta alanımızda teorik ve pratik bilgilerimizi ilk lisans eğitim de alırız."

Benzer şekilde sıklıkla ifade edilen "Kısmen Etkili” alt boyutuna ilişkin görüşlerden bazıları şu şekildedir:

"K87: Lisans eğitimi öğretmenlik hayatının \%20-25 inde etkilidir çünkü son yil yarım dönem ögrencilerle iletiism halinde oluyoruz ki biz şuan uzaktan eğitim görmekteyiz hiç öğretmen miyiz değil miyiz hiç anlayamiyoruz yöneticilerle ögretmenlerle öğrencilerle hiç iletişimimiz yok ögrencilere dokunamiyoruz göz teması kuramiyoruz ilk iki yll alan dersleri görüyoruz ama hiç faydasi olduğunu düşünmüyorum kpssye hazırlanırken herseye kendimiz çalışıyoruz eğitim derslerinde ders planı hazırlamayı ve bazı teknikleri ögrreniyoruz onların yararlı olduğunu düşünüyorum."

"K42: Fazla etkili değildir. İlk sınıflarda üstünüze öğretmen kimliği otururmakla geçerken 3 ve 4 'e doğru kpss iş bulma vs. Kaygıları etkin oluyor. Okul gerçek öğretmenlik deneyimine birşey katmadĭ̆ı gibi akademik açıdan da kalıcı öğrenmeler sunmuyor. Öğretmen adaylarının büyük bir çoğunluğu alan bilgisini kpss çalışma sürecine ve dershanelere borçlu."

"K84: Bence \%40 gibi bir oranda etkilidir. Bu oranın içerisinde de en büyük ve önemli pay formasyon derslerine aittir. Çünkü bu dersler gerçekten de oldukça nitelikli bir şekilde işlenmekte ve ögrretmenlik hayatında öğrencilere nasıl davranmamız gerektiği konusunda öğretmen adaylarını geliştirmektedir."

“Etkili Değil” alt boyutuna ilişkin görüşlerden bazıları şu şekildedir:

"K66: Etkili değildir. Lisans eğitimi daha çok seni hayata hazırlar. Lisans eğitimi aldıktan sonra direk gidip bir sinıfa ders anlatamazsın o derecede bir bilgi ve birikim sağlamıyor. Düşünmeye araştırmaya teşvik ediyor."

"K18: Biz de \%1 oraninda etkili olacak gibi. Normal şartlarda değerlendirecek olursam tabiki stajlar sayesinde ögretmenler sınıf havasını görmekte, çocuklarla iletişim kurmakta ve kendileri deneyimlemektedir. Bunlar öğretmenin meslek hayatı için çok önemli."

\section{Lisans Eğitiminin Yeterliliği Ana Temasına İlişkin Bulgular}

Öğretmen adaylarının almış oldukları lisans eğitimini sağladığı katkılar yönünden değerlendirdikleri görüşler "Lisans Eğitiminin Yeterliliği”" şeklinde belirlenen ana tema altında toplanmıştır. Sorulara yönelik cevapların incelenmesi sonucu bu kapsamda belirlenen alt temalar, görüşleri ifade eden frekans ve yüzde değerleri Tablo 9'daki gibidir:

Tablo 9. Lisans eğitiminin yeterliliği ana temasına ilişkin kategori istatistikleri

\begin{tabular}{lll}
\hline Lisans Eğitiminin Yeterliliği & f & \% \\
\hline Yeterli Değil & 49 & 30,25 \\
• Uygulama Eksikliği & 27 & 16,67 \\
- Ders İçerikleri & 9 & 5,56 \\
- Uzaktan Eğitim & 3 & 1,85 \\
- Program Eksikliği & 2 & 1,23 \\
- Teorik Bilgi Eksikliği & 2 & 1,23 \\
- Mesleğin Sürdürülebilirliği & 2 & 1,23 \\
- Aktarllabilirlik & 2 & 1,23 \\
- Verimsizlik & 1 & 0,62 \\
Kismen Yeterli & 22 & 13,58 \\
- Uygulama Eksikliği & 12 & 7,41 \\
- Nitelik Eksikliği & 3 & 1,85 \\
- Kalite Eksikliği & 2 & 1,23 \\
- Uzaktan Ĕ̆itim Yetersizlikleri & 1 & 0,62
\end{tabular}


Yeterli

- Alan Bilgisi

- Mesleki Gelişim

4

Tablo 9 incelendiğinde "Lisans Eğitiminin Yeterliliği” ana teması ile ilişkilendirilen temelde 3 alt tema ve bunlara bağlı alt boyutların olduğu görülmektedir. Öğretmen adaylarının almış oldukları lisans eğitimini yeterlilik boyutunda değerlendirdikleri ifadeler incelendiğinde belirlenen 3 alt tema arasında yoğun olarak "Yeterli Değil" alt teması kapsamında ifadelere rastlanmıştır.

Öğretmen adayları bu tema içerisinde öne çıkan "Yeterli Değil" alt temasına ilişkin süreçte çoğunlukla uygulama eksiklikleri olduğunu, ders içeriklerinin düzenlenmesine ihtiyaç duyulduğunu ifade etmiş̧tir. Bu görüşlerinden bazıları şu şekildedir:

"K5: Hayır düşünmüyorum. Her zaman teorik donanımla doldurulduk. Pratik yönden çok eksik olduğumuzu düşünüyorum. Bu nedenle mesleğe tamamıyla hazır olarak değil de o meslekte çalıştıkça profesyonel olabiliriz."

“K26: Yeterli olduğunu düşünmüyorum çünkü öğretmenlik mesleği teorik bilgiden ziyade uygulama yaptlkça ögrenilen bir meslek ve lisans eğitiminde uygulama sürecimiz oldukça klsa ve yetersiz bu sebeple lisans eğitiminin daha ilk yılından itibaren öğretmen adayı ögretmenlik mesleğiyle tanıştırılmalı ve uygulamalı olarak eğitime başlamalı."

“K47: Hayır. 21. Yüzyıl becerilerine uygun olarak revize edilmiş bir ders sistemi olduğunu düşünmüyorum. Bu çağın gerekliliklerinden en önemlisi dijitallik. Özellikle bunun ayrı bir ders olmasinı isterdim."

"Kısmen Yeterli" durumuna ilişkin süreçte uygulama eksiklikleri vurgulanarak nitelik yönünden lisans eğitiminde gelişime ihtiyaç duyulduğu belirtilmiştir. Bu görüşlerinden bazıları şu şekildedir:

“K38: Tam olarak yeterli olduğunu düşünmüyorum. Teorik dersler azaltılarak uygulamalı dersler arttırllmalı. Lisans eğitimi daha çok bilimsel odakl. Sadece lisans eğitimi alan, kendini gelişstiremeyen bir öğretmenin yeteri kadar başarılı olacağını düşünmüyorum."

"K74: Lisans ĕgitiminde aldiğım derslerin yeterli olduğunu düşünüyorum lakin yukarıda da belirttiğim gibi aldığım derslerin günlük hayattaki karşılıklarını göremediğim ya da uygulayamadlğım iç̧in edindiğim bilgilerin çoğu ögretmenlik mesleiğine başlamadan kafamdan silinmiş durumdalar. Lisans eğitimlerinde teorik derslerden ziyade pratikte uygulanabilir derslerin ağırlıkta olması gerektiğini düşünüyorum."

"K68: Mesleki açıldan yeterli gibi görünse de bazı derslerin içi boştu. Ortaokul ögrencisine aktarılamayacak bilgiler ögrrendik. Yani olmasi gerektiği kadar iyi bir ĕgitim aldı̆̆ımızı düşünmüyorum. Biz ortaokulda edebiyat anlatmayacakken dil bilgisi derslerinden çok edebiyat dersleri aldık bunun da değiştirilmesi Türkçe alanına yönelmenin gerçekleşmesi gerektiğini düşünüyorum. Bize ortaokul öğrencilerine anlatacağımız şekilde bilgiler ne yazık ki pek verilmedi bu konuya da ăğrlı verilmeli."

"Yeterli" durumu ise öğretmen adayları tarafından alan bilgisi ve mesleki gelişimin yeterli olduğu ifadeleri ile desteklenmiştir. Bu görüşlerinden bazıları şu şekildedir:

"K70: Evet yeterli çoğu ders gelişimsel açıdan yeterli ve doyurucu."

"K49: Alan hakkında yeterli seviyeye gerirebildiğini düşündüğüm için uygun buluyorum."

\section{Öğretmen Eğitimine İlişkin Öneriler Ana Temasına İlişkin Bulgular}

Öğretmen adaylarının almış oldukları lisans eğitimi çerçevesinde öğretmen eğitimine ilişkin süreçleri ve buna bağlı olarak getirmiş oldukları öneriler "Öğretmen Eğitimine İlişkin Öneriler" şeklinde belirlenen ana tema altında toplanmıştır. Sorulara yönelik cevapların incelenmesi sonucu bu kapsamda belirlenen alt temalar, görüşleri ifade eden frekans ve yüzde değerleri Tablo 10'daki gibidir: 
Tablo 10. Öğretmen eğitimine ilişkin öneriler ana temasına ilişkin kategori istatistikleri

\begin{tabular}{lll}
\hline Öğretmen Eğitimine İlişkin Öneriler & f & $\mathbf{\%}$ \\
\hline Uygulamalı Ders/Staj & 68 & 58,62 \\
Program/Ders İçerikleri & 16 & 13,79 \\
Aktif/Sosyal Ortamlar & 9 & 7,76 \\
Yöntem Teknik Çeşitleri & 5 & 4,31 \\
Değerlendirme Sistemleri & 5 & 4,31 \\
Ders Seçimi & 4 & 3,45 \\
Seminer/Eğitim Desteği & 2 & 1,72 \\
Ders Süreleri & 2 & 1,72 \\
Çözüm Odaklı Sistem & 2 & 1,72 \\
Meslek Etiği Kazanımı & 2 & 1,72 \\
Esnek & 1 & 0,86 \\
Toplam & $\mathbf{1 1 6}$ & $\mathbf{1 0 0}$ \\
\hline
\end{tabular}

Tablo 10 incelendiğinde "Öğretmen Eğitimine İlişkin Öneriler" ana teması ile ilişkilendirilen toplam 11 alt temanın bulunduğu görülmektedir. Öğretmen adaylarının almış oldukları lisans eğitimi kapsamında öğretmen eğitiminde izlenecek süreçler ya da dikkate alınacak noktaların ifade edildiği durumlar incelendiğinde belirlenen temalar arasından yoğun olarak "Uygulamalı Ders/Staj" alt teması kapsamında ifadelere rastlanmıştır. Bu önerilere ilişkin diğer alt temalar incelendiğinde bu süreçte program ve ders içeriklerinde düzenlemelere gidilmesi, aktif ve sosyal ortamların oluşturulmasına ilişkin önerilerin sunulduğu görülmektedir.

Öğretmen adaylarının bu tema içerisinde öne çıkan "Uygulamalı Ders/Staj” alt boyutuna ilişkin görüşlerinden bazıları şu şekildedir:

"K51: Uygulama derslerinin kesinlikle daha fazla üzerinde durulması ve ders saatinin arttırlmasını önerirdim. Anlayamadı̆̆ımı derslerimizi farklı yöntemler ile hoca aracılı̆̆ıyla konuşulması ve öğrencileri daha iyi anlamaya çalışmaların daha çok destek olabilmelerini isterdim. Tabiki hocalarımız yardımcı oluyor fakat yeteri kadar gelişemediğimiz derslerimiz bulunuyor."

"K5: Pratik alanlara ăgırlık verilmesini önerirdim. Ezberci katı teorik bilgiler değil de daha çok çocuğun becerilerini harekete geçirebilecek. Bir problem karşısında çözüm üretebilmeyi hedefleyen bir sistem olması gerektiğini düşünüyorum."

"K86: Uygulama derslerinin üçüncü hatta ikinci sinıftan itibaren yavaştan başlaması gerekir. Öğrencilerle nasıl iletiş̧im kurulacă̆ ve dersin nasıl anlatılması gerektiği konusunda ögretmen adayları birinci sınıftan itibaren eğitilmeli. Alan derslerine çok ağırlık verilmemeli. Yüksek lisans yapacaklar için ağırlık verilebilir."

İçerik ve konu yönünden önerilerin yer aldığı "Program/Ders İçerikleri” alt boyutuna ilişkin görüşlerden bazıları şu şekildedir:

“K42: Öğretmen fakülte sırasında değil toplumun içinde yetişmeli ki gerçekle mezun olunca karşılaşmasın. Öğretmen adaylarl aldiğ l eğitimin kalitesini gerçekten hissetmeli ve görmeli ki kendini yetersiz ve bilgisiz hissetmesin. Rehberlik derslerine daha çok önem verilmesi gerek örneğin yaratıcı drama çalışmaları arttırllmalı. sadece ileride işine yarayacak dersler yerine öğretmen adayının kendisini zihinsel ve sosyal alanda yetiştirmesini sağlayacak derslere yer verilmeli."

"K85: Eğitim derslerinin yanında çeşitli simülasyon uygulamaları kullanılabilir artık teknoloji çok ilerledi 1. Sinıftan itibaren öğrencilerle karşılaşmamı onlar için yanlış bilgiler öğrenmeye ve düzeltilmesi zor veya imkansız bir sürece neden olabilir ama sanal ögrenciler oluşturabiliriz yani yazıllımla aynı bir pilotaj eğitimi alan pilotun uçak kullanmadan önce uçak simülasyonunda eğitim alması gibi gelecek nesillerde teknolojiden faydalanarak sanal sinıfta 1. Siniftan itibaren staj yapabilir. Hatta şu an ki teknoloji ile buna alternatif olarak yapllabilecek bir başka şey google classroom 
gibi bir sınıf açıp yıl başında bir sınıf düzeyi belirlenip ona ait eğitim öğretimler o sınıfta paylaşılabilir ve sınıf üyeleri de eğitim dersleri hocalarımız olabilir."

Çevreye ilişkin önerilerin sıralandığı "Aktif/Sosyal Ortamlar” alt boyutuna ilişkin görüşlerden bazıları şu şekildedir:

"K79: Uygulamalı derslerin daha ağırlıklı olmasını fakat sınav sisteminde buna yönelik değişikliklere gidilmesini öneririm. Sinavda teorik bilginin ağırlıkta olduğu düşünüldüğ̈̈nde alanımıza uygun olmayan birçok ders verilmektedir. Edebiyat dersleri yerine dil ve dil bilgisi eğitimine ă̆ırlık verilmelidir. Öğretmen adayının aktif olacă̆l, gelişimine önem verildiği, teşvik edici, yönlendirici bir sistem geliş̧tirilmelidir."

\section{Tartışma ve Sonuç}

Öğretmenlik mesleğinin profesyonellik özelliklerini belirleme amacı ile gerçekleştirilen bu araştırmada toplanan verilerden elde edilen bulguların sonuçları şu şekilde sıralanmıştır:

Öğretmen adaylarının başlangıçta profesyonellik olgusunu kişi özellikleri çerçevesinde tanımladığı ifadelerden elde edilen sonuçlar alan uzmanı olma, meslek alanlarına bağlı olarak yeterlilik sahibi olma, duyuşsal süreçleri profesyonel kişi olarak düzenleyebilme boyutlarında yoğunluk göstermektedir. Yine alanda uzmanlaşmaya yönelik yapılan değerlendirmeler kişinin bilgi aracılığıyla donanımlı olmasıyla açıklanmıştır. Bu boyutta profesyonel kişi öğretmen adayları tarafından mesleki boyutlarla ilişsilendirilmiş ve kişiler alan niteliklerini taşıması ya da geliştirmesi durumunda profesyonel olarak değerlendirilmiştir. Alan yazında da Tanang (2014) profesyonel kişilerin mesleki eğitime sahip olması gerektiğini, belirli kalite standartlarını karşılamakla yükümlü olduğunu ifade etmiştir. Seçer (2009), profesyonel kişileri alana özgü bilgi çeşidine sahip olan ve bilgiyi uygulama boyutuna aktarabilen kişiler olarak tanımlamıştır.

Mesleki profesyonelliğe ilişkin katılımcıların görüşleri kişiyi uzman, bilgili gelişime açık olarak ifade etme yönündedir. Bu boyutlar arasında özellikle öne çıkan görüşler öğretmeni "ideal kişi” şeklinde tanımlamaya yöneliktir. Öğretmen adayları ideal öğretmeni, mesleğin tüm gerekliliklerine sahip ve bunları en iyi şekilde sürece yansıtan kişi şeklinde açıklamaktadır. Hargreaves (2000), eğitim alanının yanı sıra tüm meslek alanlarında profesyonellik kavramını kişilerin görevlerini açıklarken alana özel bilgi tabanına sahip olma, ortak uygulama standartlarını yerine getirme şeklinde ifade etmiştir. Bolam (2002) mesleki gelişimin profesyonellik ile ilişkili olduğunu vurgulamıştır. Bununla birlikte mesleki gelişimin okul için ayrılan bütçe, ulusal mesleki uygulama standartları, ulusal program, performans yönetimi ve performansa bağlı ödemeden etkilendiğini belirtmiştir. Esasında bu sonucun diğer boyutlarla da ilişkili olduğu görülmektedir. Bu yöndeki açıklamalar ideal öğretmeni başarılı, donanımlı, uzman, uygulama boyutunda yer alabilen kişi olarak detaylandırmaktadır.

Öğretmen adaylarının öğretmenlik mesleğinin sahip olduğu özellikleri açıkladığı ifadelere göre öğretmenlerin bireylerin geleceklerinin oluşumuna katkı sağladığı fikrine yönelik ifadelerin yoğunlukta olduğu görülmektedir. Bu gelecek odaklı ifadeler öğretmenliğin temel meslek ş̧eklinde nitelendirilme boyutunu da karşılamaktadır. Öğretmen adayları bu mesleği diğer mesleklere öğrenci yetiştirme, toplumu eğitme şeklinde yorumlamışlardır. Jeon, Buettner ve Hur (2016) erken çocukluk eğitimi öğretmen rollerini açıklarken güvenli, duyarlı ve destekleyici bir ortam yaratan kişilerden söz etmiştir. Benzer şekilde Parlar, Cansoy ve Kılınç (2017) destekleyici nitelikleri öğretmenlerin liderlik kültürü özellikleri çerçevesinde açıklamış ve bu özellikle birlikte öğretmenlerin iş birliği süreçlerinde aktif olduğunu ifade etmiştir. Bu yorumlamalar öğretmenlik mesleğinin rehber niteliği taşıması sonucunu beraberinde getirmiştir.

Öğretmen profesyonelliğinin sahip olunan özellikler çerçevesinde ele alındığı bir diğer temada profesyonel öğretmen olarak nitelendirilen kişilerin çoğunlukla gelişim ve yeniliğe açık, mesleki yeterliliğe ve iletişim becerilerine sahip olması gerektiği ifade edilmiştir. Bu boyutların çoğunlukla belirtilmesi eğitsel süreçlerle birlikte genel çerçevede gelişimi destekleyici ve değiş̧en süreç ile birlikte yeniliklere ayak uydurmanın gerekliliği ile ilişkilendirilebilir. Wardoyo ve Herdiani (2017) tarafından gerçekleştirilen profesyonellik aşamalarına dayalı olarak profesyonel öğretmen özelliklerinin öğretmen algıları çerçevesinde incelendiği araştırmada öğretmenlerin bu yapıyı meslektaşlar arası ilişkiler, yaşa bağlı uzmanlaşma süreçleri ile bağlantılı bulduğu belirlenmiştir. İş birliği kurma, iletişim becerilerini yerine getirme ve bunlara bağlı olarak alanda uzmanlaşmanın öne çıtığı bu araştırma elde edilen sonuçlarla paralellik göstermektedir. $\mathrm{Bu}$ çerçevede mesleki yeterliliklerin dönemin şartlarına bağlı olarak yeniden şekillendirildiği söylenebilir. Bu yönde yeterliliklerin ortaya çıkan yeni ihtiyaçları karşılamaya yönelik oluşturulması ve öğretmenlerin bu boyutlara sahip olması beklenmektedir.

Profesyonel gelişim ve bu süreci oluşturan boyutların vurgulandığı görüşlerde, sıklıkla eğitsel toplantı ve deneyimlere yönelik ifadelere rastlanmıştır. Sınıf ortamı, okul ortamı, okul dışı çevreye ilişkin düzenlemelerin profesyonel gelişimi destekleyici şekilde sürece katkı sağlayacağı ifade edilmiştir. Bayhan (2011) tarafından gerçekleştirilen öğretmen profesyonelliğinin okul yöneticileri ve öğretmen görüşlerine dayalı olarak incelendiği doktora tez çalışmasında profesyonel olma durumlarının deneyim, ortam yapısı, iş birliği süreçleri ile ilişkilendirildiği görülmektedir. Bu noktada söz konusu araştırma mevcut araştırma ile profesyonellik bileşenlerinin benzer ögelerden 
oluştuğunu öne çıkarmaktadır. Bu bağlamda profesyonel gelişimin deneyimlerle ve eğitsel basamaklarla üst düzeylere ulaşacağı sonucuna varılmaktadır. Bununla birlikte özellikle lisans eğitimi ve öğretmen eğitiminin yeterlilik boyutunda tartışıldığı ifadeler incelendiğinde öğretmen adaylarının sıkça uygulamaların eksikliğine ve bu eksiklik durumu ile ilişkili olarak uygulama süreçlerine ihtiyaç duydukları belirlenmiştir. Uygulama boyutlarının öne çıktığı bu durumlarda profesyonel gelişim ve öğretmen eğitiminin uygulamadan bağımsız düşünülemeyecek bir süreç olduğu sonucuna ulaşılmıştır.

Öğretmen adaylarına göre etkili öğretmen sosyal beceri ve sosyal alanla ilişkili olan iletişim becerisi iyi olan öğretmendir. Etkili eğitsel süreçler için bu özelliklerin edinilmesi diğer temalarda da ortaya çıkan toplumun eğitilmesi boyutu ile yakından ilişkilidir. Bu yönde sosyal çevre, iletişim süreçleri ve öğretmen yeterliliklerinin eğitsel sürecin bütününü oluşturduğu söylenebilir.

Sosyal çevre ile ilişkili görülen ve mesleki süreç değerlendirmelerinde öğretmenlerin sıklıkla karşılaşılan iş birliği boyutuna yönelik görüşler incelendiğinde iş birliğinin gelişim ve çeşitliliğe katkıda bulunduğu sonucuna ulaşılmaktadır. Bu boyutta hem kişisel hem mesleki gelişim sosyal çevrenin de etkisiyle iş birliği süreçleriyle kurulmakta ve düşünme becerilerinin oluşumuna kaynaklık etmektedir. Li (2019) tarafindan öğretmen profesyonelliğinin sahip olduğu özelliklerin incelendiği araştırmada benzer şekilde bu özellikleri oluşturan yapıların sosyal kültür, kişisel yaşantı, mesleki gelişim noktalarını içerisinde barındırdığı görülmektedir. Bu yapıların bireylerin profesyonellik algılarında etkili olduğu belirlenmiştir. Gelişim ve yeniliğe uyum sağlama gerekliliklerinin tartışıldığ boyutlara bakıldığında toplumun ihtiyaçları içerisinde bulunulan dönemin yansıması şeklinde değerlendirilebilmektedir. $\mathrm{Bu}$ bağlamda farklı düşünme becerilerinin toplumsal ihtiyaçlara cevap vermeyi sağladığı düşünülebilir. Ayrıca Yirci (2017) tarafından gerçekleştirilen öğretmen profesyonelliği ile ilişkilendirilen kişisel ve mesleki gelişim engellerinin incelendiği araştırmada öğretmenler bu engelleri mesleki gelişim açısından mevcut statü, bakanlık uygulamaları, ekonomik faktörler ve fiziki imkanlar çerçevesinde değerlendirmiştir. Kişisel gelişim önündeki engeller ise heyecan ve motivasyon bileşenleri ile açıklanmıştır. Bu engeller mevcut temaya bağlı olarak öne çıkan kişisel ve mesleki gelişimin iş birliği ile ilişkisini açıklayan boyutlarda eksik durumların göz önüne alınmasını sağlamaktadır.

Lisans eğitiminin etkililik boyutunda değerlendirildiği katılımcı görüşlerine göre lisans eğitimi öğretmenlik mesleği üzerinde etkili görülmektedir. Çetin ve Özalp (2019) tarafindan gerçekleştirilen öğretmen liderliği ve öğretmen profesyonelliğine yönelik algıların incelendiği araştırmada profesyonelliğin yaratıcılık ve üreticilik boyutlarıyla birlikte lisans eğitimi koşuluyla oluştuğu vurgulanmıştır. Bu yöndeki sonuçlar incelendiğinde her iki araştırmanın da lisans eğitiminin öğretmen profesyonelliği için ön koşul oluşturduğu düşünülebilir. İfadeler lisans eğitimi sürecinin öğretmenlere yol gösterici nitelikte olduğunu, bu sürecin öğretmen yetiştirmenin temeli olduğu yönündedir. Ancak lisans eğitiminin yeterliliğine ilişkin tema bulguları öğretmen adaylarının bu süreci yetersiz bulduklarını göstermektedir. Bu noktadaki farklılık mevcut durum ve duyulan ihtiyaç çerçevesinde değerlendirilebilir. Lisans eğitiminin yeterliliğinin değerlendirildiği ve öğretmen eğitimine ilişkin önerilerin öne sürüldüğü temalarla ilişkili olarak uygulama süreçlerinin etkili meslek edinimi şartı oluş̧urduğu düşünülebilir.

Öğretmen adaylarının çoğu lisans eğitimlerini yeterli bulmaktadır. Bazıları ise ders içeriği gibi sebeplerle kısmen yeterli bulmaktadır. Alınan derslerin içerikleri ve bu içeriklerin nitelik bakımından tartışıldığı boyutlarda mevcut yapıların geliştirilmesine yönelik önerilerin ortaya çıtığı belirlenmiştir.

Öğretmen eğitimiyle birlikte profesyonelliği sağlamayan yönelik görüşler incelendiğinde etkililik ve yeterlilik boyutlarında olduğu gibi uygulama süreçlerine yoğunlaşıldığı sonucu elde edilmiştir. Ders içeriklerinin ve mevcut öğretmen yetiştirme boyutlarının yeniden yapılanması, mevcut ihtiyaçları karşılamaya yönelik hazırlanması öğretmen adaylarının sıkça belirttiği öneriler arasında yer almaktadır. Khizar vd. (2019) tarafından gerçekleştirilen öğretmen profesyonelliği gelişiminin incelendiği araştırmada ulusal mesleki standartların profesyonellik üzerindeki etkisinin oldukça az olduğu sonucuna ulaşılmıştır. Benzer şekilde Uzun, Paliç ve Akdeniz (2013) öğretmenlerin büyük bir kısmının profesyonel olma konusunda mevcut program ve hizmet içi eğitimleri yetersiz bulduğu sonucuna ulaşmıştır. $\mathrm{Bu}$ sonuca bağlı olarak öğretmenlerin önerileri bu yapıların geliştirilmesine yönelik sonuçlar ortaya çıkarmıştır. Necheukhina, Matveeva, Babkin ve Makarova (2017) profesyonel kişilerin sistematik bir şekilde yetiştirilmesini uygulamalı eğitimler, özel eğitim kursları ve istihdam olanağı ile ilişkilendirmiştir. Mevcut araştırmadaki program ve ders içeriklerine yönelik yapılan eleştiriler öğretmen profesyonelliğinin gelişimine yönelik yeni düzenlemelere ihtiyaç duyulduğunu göstermektedir.

Elde edilen araştırma sonuçlarından hareketle profesyonelliğin kişi ve öğretmen özelliklerine yansımaları alana özgü gelişim, uzmanlık ve deneyim boyutları şeklindedir. Bu noktada kişisel ve mesleki gelişimlerle yeniliğe açık olmak öğretmenlerin taşıması gereken nitelikler arasında yer almaktadır. Söz konusu niteliklerin kazandırılması ve geliştirilmesi için eğitsel kurs ve toplantılara duyulan ihtiyaç sıkça vurgulanmıştır. T.C. Milli Eğitim Bakanlığı Öğretmen Yetiştirme ve Geliştirme Genel Müdürlüğü 2023 vizyonu çerçevesinde sunulan amaçlar, öğretmen istihdamı noktasında yüksek niteliği ön plana almaktadır. Ayrıca öğretmenlerin kişisel ve mesleki gelişimlerini sürekli kılma 
ihtiyacı doğrultusunda bu alana yönelik faaliyetler temel amaçlar arasındadır. Bu boyutta araştırma sonuçlarından doğan ihtiyaçlar sunulan temel amaçların ortak noktasına vurgu yapmaktadır (MEB, 2017).

2030 Eğitim Eylem Çerçevesi'nde öğretmen niteliğini küresel boyuta taşıma açısından nitelikli öğretmen arzını arttırma ifadesi sürdürülebilir kalkınma hedefleri arasında yer almaktadır. Öğretmen profesyonelliğine yönelik ortaya çıkan temel ihtiyaçların etkili öğrenme ortamlarıyla birlikte kişisel ve mesleki gelişimi destekleyeceği düşünülmektedir (Mundial \& UNICEF, 2016). Sunulan temel hedefler doğrtultusunda gerçekleştirilecek eğitsel faaliyetlerin profesyonel gelişime yönelik katkı sağlayacağı düşünülmektedir. İhtiyaç duyulan uygulamalar, gelecek araştırmalarla desteklenerek öğretmen profesyonelliğine yönelik ilerleme basamakları takip edilebilir. Bu boyutta gerçekleştirilecek uygulamaya dayalı bilimsel faaliyetler, literatüre katkı sağlayabilir.

\section{Araştırmacıların Katkı Oranı}

Yazarlar çalışmaya eşit oranda katkı sunmuşlardır.

\section{Destek ve Teșekkür}

Yazarlar çalışma için herhangi bir finansal destek almamışlardır.

\section{Çıkar Çatış̧ması}

Yazarlar çalışmada herhangi bir çıkar çatışmasının bulunmadığını beyan etmişlerdir.

\section{Kaynakça / References}

Altınkurt, Y. ve Yılmaz, K. (2014). Öğretmenlerin mesleki profesyonelliği ile iş doyumları arasındaki ilişki. Sakarya University Journal of Education, 4(2), 57-71.

Bayhan, G. (2011). Öğretmenlerin profesyonelliğinin incelenmesi. Doktora Tezi, Marmara Üniversitesi Eğitim Bilimleri Enstitüsü, İstanbul.

Bolam, R. (2002). Professional Development and Professionalism.

Buyruk, H. ve Akbaş, A. (2021). Öğretmenlerin Mesleki Profesyonelliği ile Özerkliği Arasındaki İlişkiye Dair Bir Çözümleme. Eğitim ve Bilim, 1-21.

Çetin, M. ve Özalp, U. (2019). Meslek lisesi öğretmenlerinin öğretmen profesyonelliği ve öğretmen liderliğine ilişkin algılarının incelenmesi. Anemon Muş Alparslan Üniversitesi Sosyal Bilimler Dergisi, 7, 193-213.

Eroğlu, M., Erdoğan, U., ve Özbek, R. (2018). Öğretmenlerin Mesleki Profesyonellikleriyle Mesleki Gelişime Yönelik Tutumları Arasındaki İlişkinin İncelenmesi / The Investıgatıon Of The Relatıonshıp Between Occuptional Professionalısm And Attitude Toward Professional Development Of Teachers. Journal of Social And Humanities Sciences Research (JSHSR), 5(30), 4379-4388.

Evans, L. (2008). Professionalism, professionality and the development of education professionals. British journal of educational studies, 56(1), 20-38.

Evans, L. (2011). The 'shape' of teacher professionalism in England: Professional standards, performance management, professional development and the changes proposed in the 2010 white paper. British Educational Research Journal, 37(5), 851-870.

Gerring, J. (2004). What is a case study and what is it good for?. American political science review, 341-354.

Habibi, B., Hartinah, S., Umam, R., Syazali, M., Lestari, F., Abdurrahman, A., ve Jauhariyah, D. (2019). Factor determinants of teacher professionalism as development of student learning education at school of SMK PGRI in Tegal City, Indonesia. Journal of Gifted Education and Creativity, 6(2), 123-132.

Hargreaves, A. (2000). Four ages of professionalism and professional learning. Teachers and Teaching, 6(2), 151-182. 
Jeon, L., Buettner, C. K., ve Hur, E. (2016). Preschool teachers' professional background, process quality, and job attitudes: A person-centered approach. Early Education and Development, 27(4), 551-571.

Karasu, K. (2001). Profesyonelleşme Olgusu ve Kamu Yönetimi. Mülkiyeliler Birliği Vakfi Yayınları Tezler Dizisi, 11, Ankara.

Karnak, B. (2020). Öğretmenlerin mesleki profesyonellikleri ile örgütsel mutlulukları arasındaki ilişki (Master's thesis, Pamukkale Üniversitesi Eğitim Bilimleri Enstitüsü).

Khizar, A., Muhammad, N. A., ve Mushtaq, A. M. (2019). Role of national education policy-2009 and national professional standards for teachers in developing teachers' professionalism. Bulletin of Education and Research, 41(3), 101. Retrieved from https://www.proquest.com/scholarlyjournals/role-nationaleducation-policy-2009-professional/docview/2376270570/se 2?accountid=15572

Kurutkan, N. (2010). Hekimlerin Profesyonelleşme Derecesi. Ankara: SAGE Yayıncılık.

Li, J. (2019). An investigation into the characteristics of teacher professionalism in a chinese higher educational institution (Order No. 28309022). Available from ProQuest Dissertations \& Theses Global. (2467472377). Retrieved from https://www.proquest.com/dissertations- theses/investigation-into-characteristicstteacher/docview $/ 2467472377 /$ se- $\quad 2$ ?accountid $=15572$

Maxwell, B., ve Schwimmer, M. (2016). Seeking the elusive ethical base of teacher professionalism in Canadian codes of ethics. Teaching and Teacher Education, 59, 468-480.

Meyer, C. B. (2001). A case in case study methodology. Field methods, 13(4), 329-352.

Miles, M. B. \& Huberman, A.M. (1994). Qualitative data analysis: an expanded sourcebook. (2nd Edition). Calif. : SAGE Publications.

Mundial, G. B., \& UNICEF. (2016). Education 2030: Incheon declaration and framework for action: towards inclusive and equitable quality education and lifelong learning for all.

Necheukhina, N. S., Matveeva, V. S., Babkin, I. A., ve Makarova, E. N. (2017, November). Modern approaches to the educational process aimed at improving the quality of highly qualified personnel training. In 2017 IEEE VI Forum Strategic Partnership of Universities and Enterprises of Hi-Tech Branches (Science. Education. , Innovations)(SPUE) (pp. 192-195). IEEE.

Parlar, H., Cansoy, R., ve Kılınç, A. Ç. (2017). Examining the Relationship between Teacher Leadership Culture and Teacher Professionalism: Quantitative Study. Journal of Education and Training Studies, 5(8), 13-25.

Robson, J. (2006). Teacher professionalism in further and higher education: Challenges to culture and practice. Oxon: Routledge.

Robson, C. (2017). Bilimsel Araştırma Yöntemleri: Gerçek Dünya Araştırması. Çev. Ed.: Şakir Çınkır, Nihan Kasımoğlu, 2. Baskı, Ankara: Anı Yayıncılık

Sachs, J. (2016). Teacher professionalism: Why are we still talking about it?. Teachers and Teaching, 22(4), 413-425.

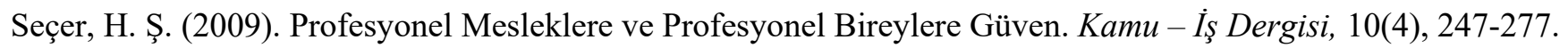

Siri, A., I Wayan, G. S., Sukaatmadja, I. P. G., ve Agoes, G. R. (2020). Does teacher competence and commitment improve teacher's professionalism. Cogent Business \& $\quad$ Management, $7(1)$ doi:http://dx.doi.org/10.1080/23311975.2020.1781993

Şenol, C. (2020). Öğretmenlerin mesleki profesyonellik algılarının mesleki statü, iş memnuniyeti ve öz yeterlik alglları üzerine etkisi (Master's thesis, İnönü Üniversitesi Eğitim Bilimleri Enstitüsü). 
T.C. Kalkınma Bakanlığı. (2018). On Birinci Kalkınma Planı (2019 - 2023): İşgücü Piyasası ve Genç İstihdamı, Özel İhtisas Komisyonu Raporu, Ankara.

T. C. Milli Eğitim Bakanlığı Öğretmen Yetiştirme ve Geliştirme Genel Müdürlüğü. (2017). Öğretmen Strateji Belgesi: $2017-2023$

Tanang, H., ve Abu, B. (2014). Teacher Professionalism and Professional Development Practices in South Sulawesi, Indonesia. Journal of curriculum and teaching, 3(2), 25-42.

Uzun, S., Paliç, G. ve Akdeniz, A. R. (2013). Fen ve Teknoloji Öğretmenlerinin Profesyonel Öğretmenliğe İlişkin Algıları, Buca Eğitim Fakültesi Dergisi, 35, 128-145.

Wardoyo, C., ve Herdiani, A. (2017). Teacher Professionalism: Analysis of Professionalism Phases. International Education Studies, 10(4), 90-100.

Werler, T. (2015). Commodification of teacher professionalism. Policy Futures in Education, 14(1), 60-76.

Yıldırım, A. ve Şimşek H. (2016). Sosyal bilimlerde nitel araştırma yöntemleri (11. Baskı). Ankara: Seçkin Yayıncılık

Yirci, R. (2017). Öğretmen profesyonelliğinin önündeki engeller ve çözüm önerileri. Ahi Evran Üniversitesi Kırşehir Ĕ̈itim Fakültesi Dergisi, 18(1), 503-522.

Zembat, R. ve Küsmüş, G. İ. (2020). Okul öncesi öğretmenlerinin sınıf yönetimi becerileri ile mesleki profesyonellikleri arasındaki ilişkinin incelenmesi. Kastamonu Eğitim Dergisi, 28(4), 1725- 1739. 